\title{
O Novo Código Civil Brasileiro: em Busca da "Ética da Situação"
}

\section{Judith Hofmeister Martins-Costa}

"A "ética da situação" inspira e governa a estrutura do Projeto, obedecendo à exigência atual do "Direito como con creșão", ou, como prefirodizer, do "Direito como experiência",

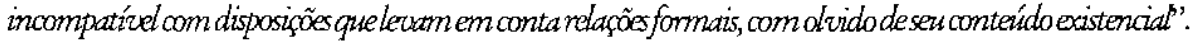

(Miguel Reale)

Sumário. Introdução. I) Estrutura e Sistema no novo Código Civil. A) A divisão em Parte Getal e Parte Especial. B) A noção de sistema que acolhe o código como "eixo central" do sistema de direito privado; b.1) pressupostos metodológicos; b. 2) um caso exemplar de "abertura e mobilidade"do sistema: os danos à pessoa. II) O Conteúdo do novo Código em suas Diretrizes Fundamentais A) A eticidade como fundamento das normas civis. B) A Socialidade como característica do Direito Civil contemporâneo; b.1) a função social da propriedade e da posse; b. 2) a função social do contrato.

\footnotetext{
: O presente estudo foi originalmente elaborado para integrar volume acerca da codificação nas Américas, a ser publicado na Revista Jurídica de la Universidad Interamericana de Puerto Rico, tendo sido também publicado na Revista Juríbica vol. 282, Porto Alegre, 2001. Em razão da recente aprovação do texto proposto e consolidado pelo Relator Geral, Deputado Ricardo Fiúza, pela Câmara dos Deputados em 15 de agosto de 2001, foram agora atualizados o título e as referências já ao "novo Código", remodelada, em parte, a estrutura do trabalho e acrescidas considerações. Agradeço o auxílio de Laura Beck Varela na revisão das notas.
} 


\section{INTRODUÇÃO}

O velho "Código de Beviláqua", o ainda vigente Código Civil Brasileiro", tido por Pontes de Miranda ${ }^{3}$ como "o antepenúltimo código oitocentista" - muito embora tendo entrado em vigor em 1916 - por seu espírito individualista, liberal em matéria econômica, conservador ao extremo nas relações familiares, está prestes a se transformar numa refetência histórica. Acaba de ser finalmenre votado pelo Congresso Nacional o Projeto de Lei $n^{\circ} 635-$ /75, que institui o novo Código Civil Brasileiro.

O novo Código, contendo 2.046 artigos, resulta de Anteprojeto elaborado pot Comissão de Juristas presidida por Miguel Reale. Para compreendê-lo, mister um olhar sobre as suas origens, que recuam, no tempo, à década de 60 , quando se fez mais forte a compreensão da necessidade de ultrapassagem do antigo Código Civil.

Foi ao aproximar-se o cinqüentenátio do Código de Beviláqua que começaram a ser ouvidas, no Brasil, as vozes defensoras de sua revisão. De um lado, os reclamos eram tributários de um movimento que então apenas se esboçava na Europa, a saber o movimento da descodificação civil, sintetizado, uma década mais tarde, no paradigmárico texto de Natalino Irti, "L'età della decodificazione"'s. De outro lado, não mais era comparivel com o ethos da sociedade brasileira o individualismo dominante no Código de Beviláqua: "individualismo possessivo" revelador da "lógica proprietária" em matéria de direitos patrimoniais, ao qual corresponde a mais absoluta avareza no tratamento dos valores existenciais ligados à vida civil ${ }^{6}$. A excelência técnica do velho Código, unanimemente reconhecida, não mais se mostrava suficiente para justificar a sua permanência.

\footnotetext{
${ }^{2}$ O vigente Código Civil resultou do trabalho de Clóvis BEVILÁQUA. Convidado em 1899 pelo Governo Brasileiro para a sua elaboração, deveria aptoveitar o quanto possível dos Projetos anteriores, desde a Consolidação das Leis Civis e o fenomenal "Esboço", de TEIXEIRA DE FREITAS (iniciado em 1859), aos Projetos de NABUCO DE ARAÚJO (1872), Felício dos SANTOS (1881) e COELHO RODRIGUES (1883). BEVILÁQUA claborou a sua obra em poucos meses. Submetido a duas revisões, o Projeto foi enviado en 1900 ao Congresso Nacional, lá tramitando por 15 anos, até que em 26 de dezembro de 1915 foi aprovado, sendo sancionado em $1^{\circ}$ de janeiro de 1916 e entrando em vigor um ano após.

${ }^{3}$ PONTES DE MIRAND, F.C, Fontes e Evolução do Direito Civil Brasileiro, Rio de Janeiro, Forense, 1981 , p. 85.

${ }^{4}$ IRTI, Natalino, L'età della decodificazione ( ${ }^{*}$ edição, 1979), que li na $3^{2}$ edição, Milão, Giuffrè, 1989.

"A expressão é de Davide MESSINETT1, "Personalitá" (Diritti della), verbete, in Enciclopedia Giuridica, Giufftè, Milão, 1984, p. 356.

"Assinala neste sentido Luiz Edson DACHIN: "O Código Civil Brasileiro, a par de ser patrimonial-imobiliário, portanto um sistema enudeado em tomo de uma nocão patrimonial fundamental, de patrimônio imobriliáno como prevalente, écoerente com a feifão dos códigos do século XIX e foi fundamentalmente feito no século passado. Outro é o borizonte contemporâneo" (Teoria Crítica do Direito Civil, Rio de Janeiro, Renovar, 2000, p. 25).
} 
É bem verdade que já em 1941 houvera uma tentativa de mudança - entretanto infrutífera - ao imaginar-se o desmembramento do Direito das Obrigações do corpus codificado, segundo o modelo do Código Suíço das Obrigações ${ }^{7}$. Porém, em 1961 Caio Mário da Silva Pereira, um dos mais conhecidos civilistas brasileiros, expressando o pensamento então dominante afirmava, em obra dídática, que "boje em dia, os juristas brasileiros estão convencidos da necessidade de ser revisto eatualizado o Código Civil".

Dando efetividade ao consenso dos juristas, o Governo Federal, naquele mesmo ano, convidou o Professor Orlando Gomes - um dos mais renomados juristas brasileiros, conhecido por suas preocupações sociais - a redigir um Anteprojeto de Código Civil, o que tomou corpo em 1963 com o contrato firmado, convertido o texto apresentado em 1964 em Projeto enviado à Câmara dos Deputados.

$\mathrm{Na}$ época, o pensamento governamental encontrava-se ainda preso à idéia de fraturar o Direito Civil, cindindo o Direito das Obrigações do corpo codificado. Tanto assim que, paralelamente ao Projeto Orlando Gomes, destinado a regular as relações de família, propricdade e sucessõcs, foi contratado, em 1963, o Professor Caio Mário da Silva Pereira, o qual, em 1964, apresentou o Anteprojeto de Código das Obrigações que elaborara juntamente com os juristas Sylvio Marcondes e Theóphilo de Azeredo Santos.

O Projeto de Código Civil de 1963, que teve como Relator Orlando Gomes", inspirado em subsídios oferecidos pelos Códigos Civis da Suíça, Itália, Grécia, do México e Peru, propunha modificações radicais na própria estrutura do Código, não mais acolhendo a divisão em Parte Geral e Parte Especial. Promovia ainda mudanças no Direito de Família que não foram bem aceitas pela comunidade jurídica, refletindo o estágio conservador então dominante na sociedade brasileira, na época antidivorcista. Assim é que, já modificado o Governo - e iniciado, em março de 1964, o longo periodo dos Governos Militares, que prosseguiu até 1985 -, foi esse Projeto ${ }^{\text {to }}$ retirado do Congresso Nacional pelo próprio Governo, para que se procedesse à sua revisão, já afastada a idéia de codificar separadamente o Direito das Obrigações.

\footnotetext{
$"$ Trata-se do Anteprojeto de Código das Obrigaçoes, elaborado pelos Professores Orosimbo NONATO, Philadelpho AZEVEDO e Hahnemann GUIMARAES.

${ }^{B}$ SILVA PEREIRA, Caio Mario, Instituiçōes de Direito Civil, v, 1, no 16, p. 15, citado por José Carlos MORerR Alves, in A Parte Geral do Projeto de Código Civil Brasileiro, São Paulo, Saraiva, 1986, p. 7

"Constituiam a Comissão Revisora também os professores Orosimbo NONATO e Caio Mário da SILVA PEREIRA.

10. Esse, na Cânara dos Deputados, tomou o n 3.263, de 1965.
} 
Por esta razão, concomitantemente ao insucesso do Projeto de Código Civil de Orlando Gomes, também a tentativa de codificar-se apartadamente o Direito das Obrigações ${ }^{11}$ acabou frustrada. No ano de 1969 , nomeou o Governo uma nova Comissão para rever e reelaborar ambos os Projetos.

Esta foi a Comissão que, presidida por Miguel Reale ${ }^{12}$ e integrada por José Carlos Moreira Alves ${ }^{13}$ (Parte Geral), Agostinho Alvim ${ }^{14}$ (Direito das Obrigações), Sylvio Marcondes ${ }^{15}$ (Direito da Empresa), Ebert Chamoun ${ }^{16}$ (Direito das Coisas), Clóvis do Couto e Silva ${ }^{17}$ (Direito de Família) e Torquato Castro ${ }^{18}$ (Direito das Sucessões), acabou por redigir o Anteprojeto, hoje em vias de se transformat no novo Código Civil Brasileiro. Deixemos Miguel Reale explicitar o perfil da Comissão que presidiu:

"Quandofui convidadopara descmpenhartão alta missão, respondia Gamae Sil wa" quenão a poderia aceitarsozinho, por considerar o mundo contemporâneo incompativel com a vaidade de legisladores solitánios, tentando repetir a façanha de Sólon, para A tenas, e de Licurgo, para Esparta. Assente a idéia de constituir-se uma Comissão Especial, procurei atender a dizersos requisitos, não só de alta competência doutrinária, mas também de afinidade intelectual, sem a qual seria impossinel levar a bom termo um trabal ho que, mais do que qualquer outro, exige barmonia das partes no todo, numa unidade sistemática. Além disto, para prevenir acusaçôes de bairrismo, julguei necessário convidar juristas de vários pontos do País, entrelaçados por vínculos de compreensão e amizade ${ }^{30}$.

\footnotetext{
${ }^{11}$ O Anteprojeto acolhia divisão tripartida, a primeira (Negócio Jurídico, Parte Geral, Contratos e outros títulos de orden geral) tendo como relator o próprio professor Caio Mário da SILVA PEREXRA, a segunda (Títulos de Crédito) sendo relatada por Theóphilo de AZEREDO SANTOS e a terceira (Empresários e Sociedades) de autoria do professor Sylvio MARCONDES.

${ }^{12}$ Jurista, professor catedrático de Filosofia do Dircito na Faculdade de Direito da Universidade de Sào Paulo, advogado.

${ }^{1.3}$ Professor catedrático de Direito Civil da Faculdade de Direito da Universidade de São Paulo, Ministro do Supremo Tribunal Federal.

${ }^{14}$ Professor catedrático de Direito Civil na Faculdade de Direito da Pontifícia Universidade Católica de São Paulo e advogado, já falecido.

${ }^{15}$ Professor catedrático de Direito Comercial na Faculdade de Direito da Universidade de São Paulo e advogado, já falecido.

${ }^{16}$ Desembargador do Tribunal de Justiça do Rio de Janeiro, professor catedrático de Direito Civil na Faculdade de Direito da Universidade Nacional do Rio de Janeiro.

${ }^{13}$ Professor catedrático de Direito Civil na Faculdade de Direito da Universidade Federal do Rio Grande do Sul, advogado, já falecido.

"* Professor catedrático de Direito Civil da Faculdade de Direito Universidade Federal de Pernambuco e advogado, jä falecido.

${ }^{19}$ Entäo Ministro da Justiça, portador do convite.

${ }^{20}$ REALE, Miguel, Memórias - vol, 2 - a Balança e a Espada, Săo Paulo, Saraiva, 1987, p. 221.
} 
Configurando uma verdadeita "escola de pensamento", formada por professores portadores de solidíssima cultura dogmática, à qual se aliava a vivência na praxis das lides forenses, sendo todos ou advogados ou juízes, os membros da Comissão Revisora e Elaboradora do Código Civil apresentaram um primeiro texro, o qual foi revisto e sistematizado por Miguel Reale em 1972. Conquanto nascida para revisar o Projeto Orlando Gomes, na verdade a Comissão apresentou um novo texto, que englobou, é certo, como subsídios, as anteriores tentativas, afirmando Miguel Reale que o Projeto Orlando Gomes refletiu-se no espírito anti-idividualista, na diretriz da socialidade que acabou por impregnar o novo trabalbo ${ }^{21}$. Este novo texto a par de superar a idéia da fratura do Código Civil, reintroduzindo no seu corpus o Direito Obrigacional, promoveu a própria unidade do Direito das Obrigações civis e comerciais, "verdadeira vocação da experiência jurídica brasileira", no dizer de Reale ${ }^{22}$, pois, antes de copiar a legislação civil italiana de 1942, mais propriamente retoma idéia do grande jurisconsul to Teixeira de Freitas que acabara não acolhida por Beviláqua ${ }^{23}$.

Do Anteprojeto é lícito afirmar desde logo que, ao cuidado com os aspectos teóricos e metodológicos, próprios dos professores, aliou-se a preocupação com os aspectos pragmáticos, atinentes à operabilidade do Direito, expressa no que Miguel Reale denominou de "diretriz da operabilidade" e sintetizada na frase de Von Jhering: "O Direito é feito para ser operado". Assim é que a Comissão, a par de propor determinada idéia de Código - que oportunamente examinarei - cuidou de melhor sistematizar instituros que, no vigente Código, vêm confundidos (como os da prescrição e da decadência), de ordenar de modo lógico os direitos e deveres (como procedeu ao distinguir, no Direito de Família, entre o direito pessoal e o patrimonial), atentando, por igual, para a simplificação de regras e para a rejeição do formalismo antiquado e estéril, ao acolher inovações tecnológicas em matéria de documentação, registros e provas. Endossando expressamente o princípio da atipicidade (art. 425) adotou, por exemplo, em relação aos títulos de crédito, uma disciplina ampla, entendendo que a disciplina da letra de câmbio, da nota promissória e dos demais títulos que

${ }^{21}$ Conforme afirmou Miguel REALE em entrevista à autora, em junho de 1998.

${ }^{22}$ REALE, Miguel, na "Exposição de Motivos do Projeto de Código Civil", ora em O Projeto de Código Civil

- Situação atual e seus problemas fundamentais, São Paulo, Saraiva, 1986, p. 71 e ss.

${ }^{23}$ Ao projetar a Consolidação das Leis Civis, aprovada pelo Governo imperial em 1858 TEIXEIRA DE FREITAS, mais de trés décadas antes da promulgação do Código Civil Alemão, já assentara a imprescindibilidade da divisào entre Parte Geral e Parte Especial para implementar a noção de sistema. Neste sentido o meu "O sistema na Codifraç̃o Civil Brasileira - de Leibniz a Teixeira de Freitas", Revista da Faculdade de Direito da UFRGS vol. 17, Porto Alegre, 1999, p. 189. 
a prática vem constantemente configurando, deve ser objeto de "leis aditivas"24, "por tratar. se de matéria em cujo âmbito são previsíveis alteraçôes a curto prazo, em função de alteraçôes econômicas ainda em processo ${ }^{325}$. Bem assim, ofereceu a criação de uma categoria intermediária de documentação de direitos creditícios, a meio caminho entre os chamados "créditos de direitos não-cambiários", oriundos de negócios jurídicos celebrados por instrumento particular ou público, e os títulos de crédito típicos ${ }^{26}$ (art. 889).

Com essas e outras inovações foi o Anteprojeto apresentado no mesmo ano de 1972 à comunidade jurídica e à sociedade, sendo, em 18 de junho de 1974, tepublicado e encaminhado ao Congresso Nacional ${ }^{27}$. Dez anos tramitou o Projeto na Câmara dos Deputados, sendo, a final, aprovado em 9 de maio de 1984, rumando então ao Senado da República, uma vez que o sistema bicameral vigente no Brasil impõe a aprovação legislativa em ambas as Casas do Congresso Nacional ${ }^{28}$.

No Senado o Projeto permaneceu por treze anos, até novembro de 1997, submergido que esteve o Brasil, desde 1985, no processo de redemocratização que implicou uma nova Constituição em 1988 e, em seguida, a edição de numerosas leis complementares à Constituição. Na legislatura de 1994, contudo, foram os trabalhos tetomados, tendo o Projeto merecido notável atualização por parte da Comissão Especial que o examinou, sendo Relator-Geral o Senador e Professor de Direito Josaphat Marinho ${ }^{29}$, com o auxilio de Miguel Reale e José Carlos Moreira Alves, os dois únicos membros da Comissão Elaboradora ainda em plena atividade, e de outros juristas e entidades ${ }^{30}$.

\footnotetext{
${ }^{24}$ A expressão é de Miguel Reale e diz respeito à própria metodologia empregada peto novo Código, que, não pretendendo tudo enrijecer em seu texto, supöe a emissão, no correr do tempo, de leis que o complementem, com maior flexibilidade inclusive no tocante ao processo legislativo, naqueles campos de vida mais suscetíveis à alterações constantes. (in Código Civil - Anteprojetos, vol. 5, Tomo 1, Senado Federal, Subsecretaria de Edições Técnicas, Brasília, 1989, p. 23).

${ }^{25}$ REALE, Miguel, in Código Civil - Anteprojetos, cit., p. 23).

2"Sobre este último ponto veja-se a análise de Mauro RODRIGUES PENTEADO, na "Exposição Justificatiza da Proposta de Modificaçâo do Titulo VII, Liemo I, Parte Especial, do Projeto de Código Civil (PLC ${ }^{\circ} 118 /$ 84) que dispõe sobre os Títulos de Crédito", in O Projeto de Código Civil no Senado, Tomo II, Brasília, Senado Federal, 1998, p. 277.

${ }^{27}$ Mensagen presidencial $n^{\circ} 160$, de 10.6.1975.

${ }^{28}$ Em virtude das alteraçōes procedidas pelo Senado no texto apreciado pela Câmara dos Deputados, o Projeto retornou a essa Casa Legislativa, onde, como já se esclareceu, fó Relator-Geral o Deputado Ricardo FIUZA.

29 A Comissão era Presidida pelo Senador Ronaldo CUNHA LIMA, sendo Vice-Presidente o Senador José Ignácio FERREIRA e Relator-Geral o Senador Josaphat MARINHO.

${ }^{30}$ Veja-se as contribuições de Fábio KONDER COMPARATO, Luis Edson FACHIN e Álvaro VILLAÇA AZEVEDO, MAURO BRANDÁO LOPES, entre outros juristas, in O Projeto de Código Civil no Senado, Tomo I, Brasília, Senado Federal, 1998.
} 
Retomando à Câmara dos Deputados em 1998, o texto recebeu ainda outras altetações, notadamente no Direito de Familìs, pata adecuá-lo às novas realidades norrnativa e sociológica -pois a instituição familiar certamenteé, dentreos tradicionais pilares do Direito Civil, a que mais fortemente sente o impacto da realidade e das mudanças de mentalidade que levam à própria positivação, compreensãoe operacionalização das normas juridicas. Em meio a fortes críticas nos meios acadêmicos, sucessivos encontros nos quais tern sido objeto de debates acirrados entre os que enfatizam os seus méritos eos partidátios da descodificação, ea oposição forrnal da Ordem dos Advogados do Brasil, o Projeto, agora finalmente aprovado, fala por si: tentando ouvir a sua voz, examinarei a sua estrutura e a noção de sistema que acolhe (Primeira Parte), e, após, as diretrizes expressivas do que há de inovador em seu conteúdo (Segunda Parte).

\section{I) ESTRUTURA E SISTEMA NO NOVO CÓDIGO}

A estrutura de um código não reflete uma opção puramente técnica, muito menos derivando do acaso ou de uma escolla arbitúnia. Antes indica uma tomada de posição metodológica reveladora de uma filosofia (A). Também assim a idéia de sistema passivel de ser retirada de um Código é claramente indicativa do seu modelo $(B)$.

\section{A) A DIVISÃO EM PARTE GERAL E PARTE ESPECIAL}

Seguindo tradição que, no Direito brasileito remonta à obta de Teixeira de Freitas, anteriot, portanto, ao próprio Código Civil alemão, sendo acolhida por Beviláqua e vigorando no atual Código Civil, também o novo Código procede à estruturação bipartida em Parte Getal e Parte Especial. Distingue-se, assim, da divisão clássica tripartite, o chamado "plano francês", no qual a regulação das matérias civis é antecedida por um Livro ou Título Preliminar sintético, com normas de sobredireito. Adota o que se convencionou chamar de "plano germânico" seguindo-se à Parte Geral a Parte Especial, composta por cinco Livros. Nesta se articulam o Livro I, concennente ao Direito das Obrigações, o Livto II, que versa o Direito de Empresa, o Livro IIl, tratando do Diteito das Coisas (Direitos Reais), o Livro IV, contendo o Direito de Familia, e o Livto V, com o Direito das Sucessões.

\footnotetext{
3i A estruturação en uma Parte Geral e uma Parte Especial é devida aos pandectistas alemães do séc. XIX. Segundo informa MOREIRA ALVES, primeiramente ela se encontra na segunda edição (1796) da obra System der gesamten heutigen Civilrechts, de DABELOW, de onde foi a idéia retirada por Gustav HUGO e, após, por Georg Arnold HEISE, que dela se utiliza em 1807 em sua obra Grundriss eines Systems des gemeinen Zivilrechts, acabando por ganhar corpo no Código da Saxônia, de 1863, e, ao final do século, no BGB (vide A Parte Geral do Projeto de Código Civil Brasileiro, cit, pp. 14 e 21).
} 
Revela esta estrutura uma opção política em tudo e por tudo diversa da existente no Código de 1.916, típico de uma sociedade patriatcal e centrada na propriedade fundiária, por isto seguindo à Parte Geral o Direito de Familia, após o Direito das Coisas, o Direito das Obrigações e por fim o Direito Sucessório. Diferentemente, o novo Código inicia com a enunciação dos direitos da pessoa e da sua personalidade, trata das obrigações civis e comerciais, unificando-as mediante o conceito de empresa - que merece um Livro próprio - só então passando aos direitos reais, ao direito das relações familiares e ao direito sucessório.

A Parte Geral é operacionalmente necessária para interligar todas as partes que compõem a estrutura codificada. Como afirmou com razão Octavian Ionescur ${ }^{32}$, o fato de a parte introdutória dos códigos civis ser estruturada ou sob a forma sintética de um "título preliminar", ou sob a forma desenvolvida de uma "parte geral" não é questão de mera técrica legislativa, comportando, ao revés, implicações de ordem científica e ideológica e, conseqüentemente, problemas de ordem teórica e prática que se refletem na noção de sistema. A ausência de uma parte geral significa a recusa à idéia de sistema enquanto encadeamento lógico-dedutivo, identificando-se, então, o termo sistema, apenas com um método de organização das matérias componentes do Direito Privado.

Diversamente, a presença de uma Parte Geral significa a ausência de "paredes internas", de modo que muito mais facilmente permite operar o que a doutrina alemã chama de "sistema móvel", isto é, aquele em que a solução prevista para determinado setor pode ser utilizada, se assim parecer útil e conveniente, para tegular outro instituto, para o qual originalmente não havia sido pensada $a^{33}$. A importância da Parte Geral está, pois, em que assegura a unidade do Código, permitindo que o direito seja construído de forma centralizada, mediante a dedução lógica entre os conceitos de maior grau de generalidade, ali postos e os institutos (casos ou espécies) versados na Parte Especial, o que não implica dizer que o sistema seja necessariamente lógico-formal, ou que a lógica formal represente o único meio possivel para este fim: o conteúdo material da Parte Geral poderá conduzir a outras acepções de sistema $a^{34}$, não se devendo confundir a "idéia de

\footnotetext{
32 YONESCU, Octavian, "Le problème de la partie introductive du code civil", Revue International de Droit Comparé, 1967, n.3, p. 579.

33 Vide CANARiS, Claus Wishem, Pensamento Sistemático e Conceito de Sistema na Ciência do Direito, trad. MENEZES CORDEIRO, Lisboa, Gulbenkian, 1989, pp. 130 e ss.

${ }^{34}$ As observações de CANARIS acerca do sistema como ordem axiológica ou teleológica estão em Pensamento Sistemático e Conceito de Sistema na Ciência do Direito, cit., pp. 66 e ss. Uma estrutura lógico-formal, desde que contenha, materialmente, principios de valor e cláusulas gerais que permitam a ligação intersistemática (por exemplo, com a Constituição) conduzirá ao delineamento do sistema como uma ordem teleológica ou axiológica.
} 
Código" característica do século XIX com cada concreto e efetivo código civil, mormente os que vêm sendo elaborados nesta nossa "era da recodificação" 35 .

$\mathrm{Na}$ Parte Geral do novo Código Civil brasileiro (arts. $1^{\circ}$ a 232 ) estão, pois, as disposições gerais aplicáveis às pessoas, aos valores essenciais da personalidade humana, ao regtamento das pessoas jurídicas, aos bens e aos fatos jurídicos, iniciando com a norma fundamental da capacidade juridica de todo ser humano ${ }^{36}$ e a regra relativa à personalização civil, iniciada do nascimento com vida, protegendo-se os direitos do nascituro desde a concepção ${ }^{37}$.

Diversamente do ainda vigente Código, no qual são ausentes as regras a respeito dos direitos de personalidade - no mais das vezes confundida com a capacidade $e^{38}$ - o Código

${ }^{35}$ A expressão remete tanto ao paradigmático texto de N. IRTI, já antes citado (L'età della decodificazione) quanto ao seu recente Codice Civile e Società Politiche, Roma, LA'TERZA,1999, no qual, com a humildade que é própria aos grandes juristas, revisa o seu entendimento, afimando que, mudado o contexto que o levara a situar a unidade do sistema, como tábua de valores coletivos, sob a garantia da Constituiçāo, esta unidade encontra-se, agyora, novamente sob a responsabilidade do Código (ver, em especial, o ensaio Códice Civile e Plusvalore Político, pp.5 a 18).

36 "Art. 10: "Toda pessoa é capaz de direitos e obrigaçôes na ordem civil", substituindowse, por pressões feministas, o termo "homem", constante do Anteprojeto, pela expressão "ser humano" e, finalmente, após a última votação na Câmara dos Deputados, empregando-se o termo "pessoa", restando a questão de saber se perceberam os Deputados (ou perceberão, dá para diante, os operadores jurídicos), a existência, ou näo de sinonimia entre os ternos "pessoa" e "ser humano", aproximando, assim, o conceito normativo ("pessoa") do conceito naturalista ("ser humano"),

${ }^{37}$ Art. $2^{\circ}$ "A personalidade civil da pessoa comę̧a do nascimento com vida; mas a lei póe a salvo, desde a concep̧ão, os direitos do nascituro".

s Como já tive ocasiano de observar, "viviamos, até há pouco, dominados pela idéia de pessoa modulada pela era codificatória, assim entendida a que seguiu-se às grandes codificações oitocentistas correspondentes à ascensão do individualismo burguês e do capitalismo. Aí foi desenhada a idéia de pessoa como "sujeito" e como "indivíduo". No discurso pandectista do século XIX, a palavra "sujeito" depreendeu-se das subjetividades que mais tarde a psicanálise viria revelar e conotou-se a uma idéia externa, objetivada, por assim dizer, a ideia de um "sujeito" que é visto tão só como "termo" ou "elemento" da relação jurídica, como aquele que pode (é capaz de) ser titular de direitos, atuando na ordem juridica. Sujeito que é privilegiadamente o "individuo", porque não mais definido pela pertença a um grupo, casta, classe, família, status, porque apartado (dividido) de um todo, de uma comunidade que o ultrapassa, significações reveladoras da "lógica proprietária" que revestiu a própria idéia de pessoa bumana. Submergida a idéia de "pessoa" na de "individuo" (ao senso "egoista" do termo) e não-visualizada a de "personalidade" pela preeminência do conceito técnico de "capacidade", traçaram-se as tramas semânticas que acabaram por fundir o "ser pessoa" com o "ser capaz de adquirir direitos e contrair obrigaçôes". Em outras palavras, instrumentalizou - se a personalidade bumana, reproduziu-se, na sua conceituaçâo, a lógica do mercado, o que conduziu à desvalorização existencial da idéia juridica de pessoa, para tornála mero instrumento da técnica do Direito" (In "Os Danos à Pessoa e a Natureza de sua Reparação", Revista da Faculdade de Direito da Universidade Federal do Rio Grande do Sul vol. 19, Porto Alegre, março 2001). 
recém aprovado dedica o Capítulo II do Livto I da Parte Geral ao seu regramento ${ }^{39}$. Em boa hota os codificadotes renunciaram tanto à tentativa de conceituar os direitos de personalidade quanto a promover a sua indicação pontual e a sua taxinomia. Esta é tarefa própria à atividade doutrinária, sabendo-se que desde que Von Gierke dedicou-se pioneiramente ao tema, a doutrina e a jurisprudência não cessam de reconhecer novas espécies de diteitos que detivam do mero fato de existirmos e possuirmos, por isso, especial dignidade ${ }^{4 i}$.

Pot esta razão, a técnica utilizada foi a das cláusulas gerais ${ }^{41}$, que permitem ranto a ligação intra-sistemática (entre as normas do próprio Código) quanto a conexão intersistemática (por exemplo, entre o Código e a Constituição) e mesmo extra-sistemática (remetendo o intérptete para fora do sistema jurídico, a fim de concretizar determinado valor ou diretiva).

Já no art. 11, detetmina setem intransmissiveis e irrenunciáveis os direitos de personalidade, não podendo o seu exercício softer limitação voluntátia, salvo nos casos previstos em lei. $\mathrm{O}$ art. 12 determina poder-se exigir que cesse a ameaça, ou a lesão, a direito de personalidade, e reclamar perdas e danos, sem prejuízo de outras sanções previstas em lei, estatuindo o art. 21 a tutela da vida privada, nos seguintes termos: "A vida privada da pessoa naturalé inviolável, e ojuiz, a requerimento do interessado, adotará as providências necessárias para impedir ou fazer cessar ato contrário a esta norma". Em outras palavras, o juiz tem o dever ${ }^{42}$ de detetminar a providência que, à vista das circunstâncias, entenda mais adequada à otimização do conteúdo das normas protetivas do art. $12 \mathrm{e}$ 21, podendo esta consistir na adoção de medida cautelar, antecipatória da tutela definitiva, na imposição de astreintes, de obrigação de não-fazer, de perdas e danos, etc.

\footnotetext{
${ }^{39}$ Acerca dos direitos de personalidade no Projeto, veja-se MARINHO, Josaphat, "Os Direitos de Personalidade no Projeto do Código Civil", Boletim da Facuidade de Direito da Universidade de Coimbra, col. Stvdia Juridica, 40, Coimbra, 2000.

${ }^{40}$ A expressäo 'direitos de personalidade" parece ter sido utilizada pioneiramente por Georg Catl NEUER, em 1866, embora a época ainda fosse fortemente marcada pela concepção savignyana do primado da relação sobre a pessoa, o que conduziu ao obscurecimento da idéía de personalidade pela noção de capacidade. Na verdade foi VON GIERKE, em 1895, no seu Deutsches Privatrecht quem primeiramente individuou estes especiais direitos subjetivos que nascem do fato de "ser pessoa", influenciando decisivamente o codificador suíço de 1907, que expressamente os previu. Para un exame veja-se HATTENHAUER, Hans, Conceptos Fundamentales del Derecho Civil, Barcelona, Ariel, 1987, e, na doutrina brasiteira mais tecente, Fachin, Luis Edson, Teoria Critica do Direito Civil, Rio de Janeiro, Renovar, 2000; LUDWIG, Marcos de Campos, "O direito ao livre desenvolvimento da personalidade na Alemanba epossibilidades de sua aplicafáo no Direito privado brasileiro" e CUNHA, Alexandre dos Santos, "Dignidade da Pessoa Humana: conceito fundamental do Direito Civil", ambos in A Reconstrução do Direito Privado - reflexos dos princípios constitucionais e dos direitos fundamentais no Direito Privado, MARTINS.COSTA, Judith(org.), no prelo e ainda o meu "Bioética e dignidade da Pessoa Humana: Rumo à Construção do Biodireito", Revista da Faculdade de Direito da Universidade Federat do Rio Grande do Sul vol. 18, Porto Alegre, 2000.

4t A propósito da metodologia no emprego das cláusulas gerais, observe-se, infra.

${ }^{42}$ Assinalo o emprego do modo imperativo no verbo "adotar, no art. 21."
} 
$\mathrm{O}$ art 13 regula os atos de disposição de próprio corpo, permitindo-se os transplantes (parágrafo único) e a disposição gratuita do próprio corpo, post mortem (art. 14), tutelando-se expressamente o direito ao nome e o pseudônimo (arts. 16 a 19), a propriedade intelectual, a honra, a imagem, a boa fama a a respeitabilidade da pessoa (art. 20).

Manteve a Parte Geral, outrossim, as normas comuns aplicáveis às pessoas jurídicas de direito público e de direiro privado (arts. 40 a 69 e 75), prevendo expressamente a desconsideração da personalidade jurídica em caso de abuso, desvio de finalidade ou confusão patrimonial (art. 50). Na origem desta regra está sugestão do Ptofessor Fábio Konder Comparato, da Universidade de São Paulo, que assim se pronunciou: "Épreciso distinguir, cuidadosamente, entre despersonalização e desconsideração da personalidade jurídica. (... ).A desconsideração da personalidade não suprime a autonomia subjetiva da pessoa jurídica, como ente distinto da pessoa de seus sócios ou administradores, mas afasta-a tão só provisoriamentee para o caso concreto. É, portanto, uma técnica de efeitos relativos $(. . .)^{43}$.

A causa da desconsideração, isto é, o abuso, deve ser buscada no desvio dos fins estabelecidos no contrato social ou nos atos constitutivos, podendo consistir também o abuso, como alerta Comparato, na confusão entre o patrimônio social e o dos sócios ouadministradores ainda que mantida a mesma atividade prevista, cstatutária ou contratualmente" ${ }^{\text {s"r }}$.

$\mathrm{Na}$ regulação dos Bens (Livro II) o novo Texto Civil inova ao distinguir os acessórios e as pertenças (que não são partes integrantes) no art. 93, determinando no art. 94 que os negócios jurídicos que dizem respeito ao bem principal não abrangem as pertenças, salvo se o contrário resultar da lei, da manifestação de vontade ou das circunstâncias do caso. Como explica Clóvis do Couto e Silva ${ }^{45}$, no que toca aos bens, os códigos italiano e português estabeleceram a distinção entre parre integrante essencial, parte integrante não-essencial e pertenças, assim considetadas as coisas destinadas permanentemente ao serviço ou ao onnamento de outra coisa cuja característica $\hat{e}$ - diversamente dos bens acessórios, sujeitos ao "princípio da gravitação jurídica"

\footnotetext{
4. COMPARATO, Fábio Konder, Correspondência dirigida ao Senador Josaphat Marinho em 3.9.97, in O Projeto de Código Civil no Senado, Tomo Ir, Brasília, Senado Federal, 1998.

${ }^{44}$ Idem.

${ }^{45}$ COUTO E SILVA, Clóvis, "Observaçôes à Parte Geral do Anteprojeto de Código Civil", dirigidas ao Relator José Carlos MOREYRA ALVES em março de 1970, reproduzidas nas notas de rodapé da "Análise das Observafoóes do Prof. Couto e Silva à Parte Geral do Anteprojetode Código Civil", in A Parte Geral do Projero de Código Civil, cit., pp. 39 a 42.
} 
- suportar relação jurídica própria ${ }^{46}$.

A distrinção tem importância porque, de modo geral, nas codificações latino-americanas, incluso o vigente Código Civil brasileiro, vigora o axioma de que o vendedor, na dúvida, tem que entregar ao comprador a coisa com as pertenças. Contudo, podem existir, e efetivamente existem, diversos graus de vinculação entre as coisas. Adotando-se uma perspectiva escalonada do ordenamento jurídico, observa-se que uma vinculação mais íntima dará lugar à noção de parre integtante essencial, como a que liga uma edificação ao terreno no qual construída. Uma vinculação não tão íntima dará lugar à categoria das partes integrantes não-essenciais, como a que vincula uma fábrica ao seu maquinário. Num grau mais distante estarão as pertenças, configurando-se o grau do liame pela concreta natureza da relação, pelas circunstâncias, pelos usos, pela lei ou pelo exetcício da autonomia privada ${ }^{47}$.

Já o Livro III trata dos Fatos Jurídicos. Aqui se contêtm as maiores inovações respeitantemente à disciplina do Código Civil vigente, a iniciar pela denominação "Do Negócio Jurídico" - constante de seu Título I, especificando-os e recortando-os da categoria geral dos Atos Jurídicos, o que tem evidentes reflexos práticos, não se tratando de mero nominalismo. Aos atos jurídicos lícitos stricto sensu e aos atos-fatos (ou "atos reais", na terminologia portuguesa, denominação derivada da doutrina alemã) aplica-se, apenas no que couber, a disciplina reservada aos negócios (art. 185), assim seguindo a metodologia adotada no Código Civil português de 1967, como esclarece José Carlos Moreira Alves, o Relator da Parte Geral ${ }^{48}$.

O Livro III inicia, pois, com a regulação dos Negócios Jurídicos (Título III), cujas disposições gerais abarcam as regras de sua validade (art. 104), da impossibilidade do objeto quando de sua celebração (art. 106), determinando que esta não invalida o negócio, se relativa; ou, se absolura, só quando cessar antes de realizada a condição a que estiver subordinada. Contém, por igual, regra acerca do silêncio (art. 111), que importa anuência quando as circunstâncias ou os usos o autorizarem, dispondo, no art. 113, acerca da interpretação ("Os negócios jurídicos devem ser interpretados conforme a boa. fé e os usos do lugar de sua celebração"), o que conduzirá - oportunamente o veremos - à eticidade como uma das marcas do novo Código.

\footnotetext{
${ }^{46}$ Sobre as pertenças veja-se PONTES DE MIRANDA, Tratado de Direito Privado, Tomo II, Rio de Janeiro, Borsói, 154, parágrafos 127 e 138, e FRADenA, Vera Maria JACOB de, "Pertenças", Revista Juridica 126, Porto Alegre, 1988.

4? Para estas observaçóes veja-se COUTO E SILVA, in MOREIRA ALVES, op. cit., nota 5, pp. 39 240.

48 MORETRA ALVES, José Carlos, op. cit.,p. 98.
} 
Superando a linguagem oitocentista que tratava dos "vícios do consentimento", o Código recém aprovado, mais adequadamente versa, no Capítulo IV do Livro III da Parte Geral, sobre os Defeitos do Negócio Jurídico - o erro ou ignorância (arts. 138 a 144), o dolo (art. 145 a 150), a coação (art. 151 e 155), o estado de perigo (art. 156) e a lesão (art. 157). Acerca destes dois últimos cabe breve consideração, pois o primeiro introduz, e o segundo reintroduz, no Direito brasileiro, expressivas alteraçōes.

$\mathrm{O}$ "estado de perigo" configura-se "quando alguém, premido da necessidade de salvar-se, ou a pessoa de sua familia, de grave dano conbecido pela outra parte, assume obrigação excessivamente onerosa', estendendo-se a regra inclusive para pessoa não integtante da família do declarante, hipótese em que o juiz decidirá "segundo as circunstâncias". Tratase de hipótese em que alguém se obriga a dar ou a fazer (prestação) por uma contraprestação sempre de fazer, como esclateceu Moreira Alves ao dar parecer opinativo da rejeição à emenda senatorial que visava simplesmente a suprimir o art. 156, sob o argumento de que o mesmo estaria confundido com o instituto da lesão "com grande prejuizo para os interesses e a validadedos contratos em geral" ${ }^{149}$.

Preceito similar constava do Projeto de Beviláqua, tendo sido suprimido pela Comissão Revisora 'sem que se saibam os motivos que a isto conduziram" ${ }^{\text {soo }}$. Uma hipótese que avento para a supressão, há quase cem anos, e para os protestos que ainda hoje gera esta regra ${ }^{51}$ é a sua imensa potencialidade social, que, como é sabido, incomoda ao pensamento conservador. Com efeito, no seu substrato não está a ficção da igualdade das partes, de modo que a regra terá relevância na tutela do contratante fraco: figurese a hipótese de, numa internação hospitalar de urgência, a entidade obrigar o doente, ou os seus familiares, a assumirem pesada obrigação financeira, sob pena de, assim não procedendo, não se realizar o tratamento, ou não se fazerem exames que seriama devidos, ou não ministrar o dispendioso medicamento!

Do mesmo modo que o "estado de perigo", a invalidade (anulabilidade) por lesão (art. 157) constitui novidade em relação ao Código vigente, muito embora o instituto da lesão, com origens romanas, mas elaborado pelo ius commune, seja figura

\footnotetext{
4) Emenda $\pi^{\circ} 20$, de autoria do Senador Gabriel HERMES, in O Projeto de Código Civil no Senado, Tomo I, Brasília, Senado Federal, 1998.

51) OREIRA ALVES, José Carlos, A Parte Geral..., cit., p.108.

5! Assim editorial no conservador jornal O ESTADO DE S. PAULO de 6 de janeiro de 2001.
} 
antiquíssima em nosso Direito: previsto em Portugal desde o séc. XIII ${ }^{52}$, mantido nas Ordenações Filipinas (Livro IV, Titulo XIII) foi expressamente acolhido por Teixeira de Freitas na Consolidação das Leis Civis (art. 359), ai estatuindo o que Ruy Rosado de Aguiar Júnior qualificou de "lesão pura, onde não bavia vício de vontade, mas rescindibilidade fundada na simples quebra de equivalência entre as prestaçóes, objetivamente verificada $a^{53}$.

A reintrodução destes instituto é cambérn reveladora da "ética da situação" que marca o novo Código. Bevilácqua eta frontalmente contrário, em nome do "princípio da autonomia da vontade", posicionando-se antagonicamente, pois, ao intervencionismo estatal representado pelo poder dado ao juiz de apreciar a lesão. Para tanto, argumentava, como base no Direito Comparado, que "as legislaçôes mais modernas" haviam abolido o instituto, invocando também razões de ordem sociológica: desse ponto de vista, escreveu, só se admite a tescisão por lesão "nas épocas em que o Estado necessita exercer uma tutela mais direta e contínua sobre a vida privada dos individuos, porque esses não se sentem assaz fortes contra a prepotência e contra a cobiça, e porque, entre as classes sociais, bá um verdadeiro contraste ${ }^{54 "}$.

Ressurgitá a lesão, apenas sob a forma da usura, no campo penal, no final da década de $30^{55}$, sendo fixada como crime contra a economia popular na Lei n ${ }^{\circ} 1.521 / 51$. Porérn, até recentemente, no campo civil, era totalmente afastada. Dos taros acórdãos indexados na

\footnotetext{
52 Segundo Antonio HESPANHA, a lesäo ingressa na Idade Média através de uma Dectetal do papa Gregório IX (1234), que, por sua vez, se baseava na teoria escolástica do "justo preço"(ver, do autor, a "Nota do Tradutoz", à Pg. 741 da obra Inrrodução Hisrórica ao Direito, de GILISSEN, J. Lisboa, Gulbenkian, 1988). Outros autores, como o argentino MOISSET DE ESPANES, situarn a sua fonte canônica em duas Decretais, una de Alexandre III, no ano de 1170 , relativa à venda de um bosque pela metade do valor, e a outra de Inocêncio III, do ano de 1208 , que trata também da venda de um imóvel pela metade do valor (OISSET DE ESPANES, Luis, La lesión los Acros Juridicos, Cordoba, Victor P. De Zavalia Editor, 1979, p. 56 e $57 . E m$ Portugal, especificamente, a lesão foi recebida nos finais do séc. XIII, sendo consagrada nas Ordenações Afonsinas (IV, 45) Manuelinas (IV, 30) e Filipinas (Liv. IV, T.13): ai se declarava que o contrato de compra e venda de bens móveis ou imóveis (bens de raiz) embora "perfeito", poderia ser desfeito se una das partes tivesse sido enganada além da metade do justo preço, distinguindo-se entre a lesão "enorme" e a "enormíssima" de forma tarifária.

53 AgUIAR JúNIOR, Ruy Rosado, "Cláusulas Abusivas no Código do Consumidor", in A Proreção do Consumidor no Brasil e no Mercosul, MARQUES, Cláudia Lima (org.), Porto Alegre, Livraria do Advogado, 1994, p. 16.

${ }^{54}$ BEVILÁQUA, Clóvis, Projeto de Código Civil Brasileiro, Trabalhos da Comissão Especial da Câmara dos Deputados, VI, p. 8, citado por SILVA PERJira, Caio Mario, Lesão nos Contratos, Rio de Janeiro, orense, $4^{2}$ Edição, 1993, p. 97.

${ }_{55}$ Em 1938, Decreto Lei no 869 , definiu como crime contra a economia popular a usura pecuniária, ou raal e definis o crine"'obter ou estipular, em qualquer contrato, abusando da premente necessidade, inexpeniencia ou leviandade da oucra parte, hacro patrimonial que exceda o quinto do zalor corrente ou justo da prestaçáo feita ou prometida. O elemento subjetivo estava justamente na causa, ou seja, abusar da necessidade inexperiência ou leviandade da outra parte, para obter vantagem patrimonial, residindo o elemento objetivo na ruptura da igualdade das prestações, exigido que se observasse uma "igualdade parcial" (garantindo o hcro), o qual não poderia exceder de $20 \%$ o justo valor. No Estado Novo, Carta Constitucional de 1937, determinou, no art. 142: "A usura será punida". E, finalmente, a Lei $\mathrm{n}^{\circ}$ 1521, de 26 de dezembro de 1951, ao definir os crimes contra a economia popular, preceituou igualmente o crime.
} 
jurisprudência eletrônica do Supremo Tribunal Federal está o que afirma a "impossibilidade" $\mathrm{da}$ anulabilidade de contrato por lesão, pois "desde que o Código Civil regulou a matéria relativa aos atos jurídicos e especificou os vícios do consentimento, excluindo a lesão, é evidente que esta não constitui mais motivo de anulação dos contratos"s.

Como defeito do negócio jurídico que leva à sua rescisão, a lesão reingressa apenas no Código de Defesa do Consumidor - embora não com este nomem iuris (art $6^{\circ}$, inc. V, primeira parte) valendo para as hipóteses de abusividade contratual, reguladas no art. 51. Aí, como ensina Ruy Rosado de Aguiar Júnior, a ação de que dispõe o consumidor é a ação de modificação do contrato, fundada no desequilíbrio entre as partes já existente ao tempo da celebração ( $\operatorname{arr} 51, \int^{\circ}$ ), com o objetivo de eliminar a cláusula ou alterat o seu conteúdo, mas sempre mantendo o contrato em razão do princípio da conservação do negócio ${ }^{57}$. Porém, na hipótese de não ser possivel a alteração do contrato ou suptessão da cláusula, é permitida a ação de rescisão do contrato, por lesão.

Fora desta hipótese, que se subsume na abusividade contratual e é específica para as relações de consumo, a lesão só agora alcança o nosso direito privado com caráter de regra geral no art. 157 do novo Código.

Neste ocorte o defeito no negócio jurídico "quando uma pessoa, sob premente necessidade, ou por inexperiência, se obriga a prestação manifestamente desproporcional ao valor da prestação oposta", admitindo a lei a suplementação da contraprestação, ou a redução do proveito, para afastar a conseqüência anulatória.

O reingresso da lesão em nosso ordenamento civil não foi tranqüilo: no Senado o atual art. 157 sofreu emendas, uma proposta pelo Senador Jutahy Magalhães, que queria nova redação, para subordinar a lesão ao dolo, outra proposta pelo Senador Gabriel Hermes ${ }^{58}$, que queria climinar a expressão "por inexperiência do agente" como causa de invalidiação do negócio jurídico, restringindo-a apenas à "premente necessidade" do lesado.

Mas, felizmente, as emendas foram rejeitadas, seguindo-se a opinião de Moreira Alves, segundo o qual a lesão ocorre quando há a "usura real", não sendo necessário que a

\footnotetext{
56 RE 82971/RS, Rel. Min. Cunha Peixoto, ${ }^{2}$ T. j. 26.10.76, p. em DJ de 31, 12.76 e in RTJ vol. 84 p. 218).

${ }^{57}$ ROSADO DE AGUIAR, Ruy, "Aspectos do Código de Defesa do Consumidor" Revista Ajuris, vol. 52. Vejase do mesmo autor "Cláusulas Abusivas no Código do Consumidor", citado, p. 16."

${ }^{58}$ Assim pronunciounse MOREIRA ALVES ao dar parecer sobre a emenda supressiva do Senador Gabriel Hermes: "A lesão ocorre quando há a ustra real. Não há, na lesão, ao contrário do que ocorre com o estado de perigo, que vicie a simples oferta. Ademais, na lesão não épreciso que a outra parte saiba da necessidade ou da inexperiência: a lesão é objetiva. Já no estado de perigo é preciso que a parte beneficiada saiba que a obrigafão foi assumida pela parte contrária para que esta se salve de grave dano (levando-se en conta, pois, elemento subjetivo"). In O Projeto de Código Civil no Senado, Tomo II, Brasilia, Senado Federal, 1998, p. 015.
} 
outra parte saiba da necessidade ou da inexperiência, pois "ao contrário do que ocorre com o estado de perigo em que o beneficiário tem que conbecê-lo, na lesão o próprio conbecimento é indiferente para que ela se configure"s9, o que significa dizer que em nosso Direito mantém-se a tradição salutar de considerar a lesão objetivamente.

Também seguindo a tradição que vem do ius commune, expressa nas Ordenações e na Consolidação de Teixeira de Freitas, o negócio pode convalescer, se for oferecido suplemento, determinando o Código que a desproporção se apure segundo os valores vigentes ao tempo do ato (art. $157, \$ 1^{\circ}$ ), o que indica se ter afastado, o novo Código, não só do sistema francês, mas também do sistema alemão e do italiano - e, portanto, do adotado pelo Código Civil português de 1967 - não se preocupando em punir a atitude maliciosa do favorecido, mas em turelar o lesado ${ }^{63}$.

A lesão introduzida no novel Código é um defeito que se instala no momento da conclusão do negócio, já impedindo a formação do sinalagma genético, razão pela qual, no meu entender, pressupõe contrato oneroso, bilateral e comutativo, conduzindo ao seu desfazimento. É defeito do negócio, centrado em dois elementos característicos, a desproporcionalidade das prestações e a premente necessidade ou a inexperiência. Esta, como acentua Caio Mário da Silva Pereira ${ }^{61}$, não reside no fato de o contratante ser levado a concluir o contrato em virtude de maquinaçōes da outra parte, ou de ser coagido a fazê-lo (vis compulsiva), antes sendo caracterizada pelo efetivo pouco trato do lesado com aquele tipo de contrato, seja porque não-afeito aos negócios, ou porque catente de conhecimento sobre a natureza do contrato que celebra, v.g., por não dispor de informação adequada acerca do negócio que realiza, ou sobre as reais condições do metcado.

No tratamento dos atos ilícitos o novo Código prevê a possibilidade de dano extrapatrimonial (art. 186,) que chama de "dano moraliz", cabendo entretanto notar que, muito embora, a rigor, esta denominação seja adequada não para o gênero, mas para uma das espécies de dano extrapatrimomial, é corrente na doutrina e jurisprudência

\footnotetext{
5\% MOREIRA ALVES, Idem, ibidem.

${ }^{60}$ MOREIRA ALVES, Idem, ibidem.

"SILVA PEREIRA, Caio Mario, Lesão nos Contratos, cit., p. 199.

${ }^{22}$ Art 186: "A quele que, por ação ou omissâo voluntária, negligência ou imprudência, violar direito ecausar dano a outrem, ainda que exclusivamente moral, comete ato ilicito".
} 
brasileiras como designativa do gênero, podendo-se afirmar que, nuito embora as distinções feitas pela doutrina mais rigorosa, no Brasil, as expressões "dano moral" e "dano nãopatrimonial" são utilizadas como sinônimas ${ }^{63}$.

Juntamente a esta cláusula geral de ilicitude, fundada na culpa, o novo Texto reserva, no art. 187, cláusula geral de ilicitude, de índole objetiva ${ }^{64}$. Esta norma constitui, na abalizada opinião de Ruy Rosado de Aguiar Júnior, "regra quase perfeita, que servirá para iluminar todo o Direito Obrigacional no Brasil' ${ }^{65}$ ". A sua importância está em que deixa claro o injustificável equívoco de grande parte da doutrina e da jurisprudência brasileiras ao situar o abuso apenas quando há a intenção de prejudicar (o que efetivamente não se retira da literalidade do art. 160, I do Código vigente), indo além, por reunir, num mesmo dispositivo, referência a quatro princípios fundamentais do ordenamento: o abuso de direito, offm social, a boafé e os bons costumes.

${ }^{63}$ A legislação brasileira utiliza a expressão "dano moral" para referir-se a todas as espécies de danos não-patrimoniais, assim constando do art. $5^{\circ}$, incisos V e X da Constituição Federal, e da legislação especial. A mesma denominação é seguida por gxande parte da doutrina e da jurisprudência, encontrando-se a distinção seja entre danos morais subjetivos e objetivos, seja entre danos morais diretos ou indiretos para especificar aqueles que dizem respeito diretamente à esfera da mais direta subjetividade e os que atinem à repercussão social da esfera da personalidade (Veja-se, exemplificativamente, José de AGUIAR DIAS, Da responsabilidade Civil, Rio de Janeiro, Forense, Tomo II, 1994, 713; Carlos Alberto BITTAR, Reparação Civil por Danos Morais, São Pauło, Revista dos Tribunais, $3^{a}$ edição, $2^{2}$ tiragem, 1999; Yussef SAID CAHALI, Dano Moral, $2^{a}$ edição, São Paulo, Revista dos Tribunais, 1998; Amoldo MEDEIROS DA FONSECA, Dano Moral, verbete in Repertório Enciclopédico Brasileiro, vol. 14, 241). Raros são os textos, doutrinários ou jurisprudenciais, que utilizam a expressão "danos à pessoa" para indicar a vasta categoria dos atentados à personalidade, como o faz Clóvis do Couto e Silva, o qual, todavia, realiza a sinonínia entre dano moral e dano extrapatrimonial que já havia sido contestada nos anos 60 , con integral pertinência, por Pontes de Miranda (Vide Clóvis DO COUTO E SILVA, "O conceito de dano no Direito brasileiro e comparado", in $\mathrm{O}$ Direito Privado Brasileiro na visão de Clóvis do Couto e Silva", ao cuidado de FRADERA, Vera Maria Jacob, Porto Alegre, Livraria do Advogado, 1997, 217). Diversamente, PONTES DE MIRAND $\Lambda$ já na década de 50 acentuava ter a expressão "dano moral" concorrido "para graves confusões", explicando: "As vezes, os escritorese juizes dissertadores empregam a expressĩo "dano moral" em sentido amplíssimo (dano à normalidade

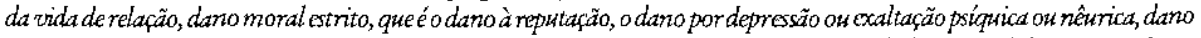
que não é qualquer dos anteriones mas tambóm não ofende opatrimônio, como a dor sofrida, o de destruição de bem sem qualquer zator patrimonial ou de ualor fatrimonial ínfino. Ai dano moral seria dano não patrimonial. Outros têm como dano monal o dano à nonmalidade da vida de relação, o dano que faz baixar o moral da pessaa e o dano à reputa̧̧ão. Finalmente, há o senso estrito de dano moral: o dano à reputação "(PONTES DE MIRANDA, Tratado de Direito Privado, $T$. 26, E3. Borsói, Rio de Janeiro, 1959, parágrafo 3.108, 31, gxifos do autor).

${ }^{64}$ Art. 187: "Comete ato ilícito o titular de um direito que, ao cxercêllo, excede manifestamente os limites impostos pelo seu. fim exonômico-social pela bad-fé ou pelos bons costumes".

${ }^{65}$ A GUIAR JUNIOR, Rui Rosado, "Projeto do Código Civil - Obrigaçôes e Contratos", Revista do Conselho da Justiça Federal v.9, Brasília, 1999, p. 31, também disponível em http://www. cjf.gov.br/Publicacoes/ Publicacoes.asp. 
No que concerne ao regramento da prescrição e da decadência - tema tormentoso no Código Civil vigente, que mistura ambas as espécies - o novo Código adotou interessante solução metodológica: trata sistematicamente apenas da prescriçăo (art. 189 a 196), enumerando as hipóteses na Parte Geral (art. 206) e acoplando as regras relativas à decadência em cada preceito onde cabível, salvo a tegulação genérica dos arts. 207 a 211 . Sabe-se que a prescrição é o encobrimento dos direitos análogos à pretensão, enquanto a decadência trata da extinção dos direitos potestativos, de modo que a solução adotada é extremamente operativa, motivo pelo qual Reale com ela exemplifica a diretriz da operacionalidade que dominou, entre outros, os ttabalhos codificatórios ${ }^{66}$.

A Parte Geral encerta com as regras relativas à prova dos fatos jurídicos (art. 212 e ss), regulamentando a confissão (arts. 213 e 214), e admitindo no art. 225 , quaisquer reproduções fotográficas, fonográficas, cinematográficas e, em geral, quaisquer reproduçōes mecânicas ou eletrônicas de fatos ou coisas, salvo impugnação da parte contrária.

Se a Parte Geral corresponde - para usar antigo clicbê - "ao que, na matemática, vem antes do parêntese", definindo, assim, a possibilidade de um sistema interno inconfundjuel com a meta ordenação extrínseca das matétias é porque, da estrutura calcada numa Parte Geral e numa Especial decorre certa unidade lógica e conceitual, o que Miguel Reale denominou de diretriz sistemática ${ }^{67}$.

Porém, não se confunda a diretriz sistemática com a "idéia de sistema" construída, desde o Justacionalismo, como um abstrato modelo geométrico. A ditetriz, aqui, diz mais de perto com a noção de unidade. Como afitma Irti, hoje em dia o Código Civil reassume uma decisiva posição histórica, poiss, acolhendo princípios, custodiando técnicas de disciplina e categorias ordenatórias, tem novamente "la responsabilità dell'unità", suprindo a Constituição, que não pode tudo prever e está mais fortemente sujeita aos azares da política, desenvolvendo então o Código a função de garantia e protegendo a continuidade da vida civil $^{68}$.

Bem por isto, no novo Código Civil a estrutura sistemática, não estática e fechada, nas aberta e móvel, uma vez centrar-se em numerosas cláusulas gerais, é completada pela obra de implementação da unidade do Direito das Obrigações, que, na verdade, é uma realidade independentemente da previsão codicista: nosso Código Comercial de 1850, por demais vetusto e totalmente recortado por leis especiais de há muito tem, para a prática juridica brasileira, valot meramente residual .Como assinala Reale, 'na realidade o Direito das Obrigações, na matéria civil, é hoje tábua reguladora também das obrigaçôes de natureza

${ }_{66}$ REALE, Miguel, O Projeto de Código Civil - situação atual e seus problemas fundamentais, São Paulo, Saraiva, 1986, pp. 11 e 12.

${ }^{67}$ REALE, Miguel, O Projeto de Código Civil - situação atual e seus problemas fundamentais, São Paulo, Saraiva, 1986, pp. 5 a 7.

${ }^{68}$ IRTI, N. Diritto Civile e Società Política, cit., p.15. 
empresarial, de natureza mercantil ou industrial' ${ }^{169}$.

A unidade do Direito Obrigacional é assegurada pela disciplina juridica da Empresa (Livro II da Parte Especial). Partiram os codificadores do pensamento de que o modelo jurídico da empresa não é uma criação do Direito, a ele antecedendo a sua existência como realidade econômica, constatação relevante por salientar a existência de forças sociais que exigem uma constante resposta do Direito ${ }^{7 /}$. Forte nesta premissa o Código ora aprovado recusa-se a conceituar a empresa, disciplinando-a, todavia, sistematicamente, a partir da noção do empresário como aquele que "exerce profissionalmente atividade econômica organizada para a produção ou a circulação de bens ou de serviços" (arr. 966").

Muito embora a unificação do Direiro Obrigacional proposta no novo Código Civil brasileiro não constitua cópia das legislações suíça e italiana, que também a assegutam pois, como visto, uma tal estrutura já havia sido imaginada no século XIX pelo grande Teixeira de Freitas- é bem verdade que algumas das regras relativas à disciplina da empresa têm inspiração iraliana ${ }^{72}$. Assim, o próprio conceito de empresário (art. 966), que corresponde ao disposto no art. 2.082 do Codice Civile, o que foi aceito pela Comissão Elaboradora "porque as notas da definição reproduzem, em grande medida, o conceito econômico de empresa"s?.

A empresa pode ser exercida por uma pessoa isoladamente, o empresário, pessoa física, ou por uma sociedade, hipótese enn que se configurará a sociedade empresária (art. 982). A nova Lei Civil divide as sociedades em não personifícadas (Livro II, Título II, Subtítulo I, e personificadas (Subtítulo II), não admitindo, porém, as sociedades unipessoais.

A sistematização em termos amplos, com um sentido muiro mais de "ordenação da prática social" do que propriamente uma intervenção de tipo "regulativo", pode também ser observada no que concerne às sociedades. O novo Código distingue as pessoas jurídicas de direito privado sem fins lucrativos (associaçöes) das com fins econômicos (sociedades), tratando das primeiras no Título II do Livro I da Parte Geral. As sociedades encontram-se divididas em sociedades empresárias e sociedades simples, sendo as primeiras as que têm

\footnotetext{
${ }^{69}$ Idem, p. 6.

"Veja COUTO E SLLVA, Clóvis, "O Conceito de Empresa no Direito Brasileiro", Revista Ajuris vol. 37, p. 42 e ss.

11 O parágrafo único do art. 966 exclui da noção de empresário "quem exerce profissão intelectual, de natureza cientifica, literária ou artística, ainda com o concurso de auxiliares ou colaboradores, salvo seo exercício da profissão constituir elemento da empresa".

72 Veja-se, a propósito, o estudo de MAC.DONALD, Norberto da Costa Caruso, O Projeto de Código Civil e o Direito Comercial, Revista da Faculdade de Direito da UFRGS, vol. 16, Porto Alegre, 1999 , p. 139.

7 Assim, COUTO E SillVA, Clóvis, "O Conceito de Empresa no Direito Brasileiro", cit, p. 51 . Anote-se que - Senado, mediante a Emenda ${ }^{\circ} 68$, ainda mais aproximado o modelo do novo Código do modelo italiano.
} 
por objeto o exercício da atividade própria de empresário, sujeito a registro, assim consideradas, independentemente de seu objeto, as sociedades por açōes, e, simples, as cooperativas ${ }^{74}$.

O grande valor de nosso novo Código, mormente se comparado com o seu congênere italiano está, nessa matéria, na adstrição à diretriz sistemática: não regulando o Direito do Trabalho, que no Brasil tem diploma próprio ${ }^{75}$, o novo Código promove a sistematização da disciplina da empresa sem cindir as suas regras das demais normas de direito privado nem confundi-las com as especificidades da disciplina das relações de emprego.

À disciplina da Empresa segue-se o Direito das Coisas (Livro III), do Direito de Família (Livro IV) e o Direito Sucessório (Livro V). Destes, o Direito de Familia - justamente o que menor undade apresenta, em razão das múltiplas e às vezes antinômicas emendas que o Projeto sofreu, para adequá-lo às novas realidades normativas e sociológicas - é o que contém, no que concerne à estrutura no qual assentado, a mais peculiar e elaborada forma de ordenação.

É que a regulação tradicional do Direito de Familia, tal como aparece no ainda vigente Código, não contém a divisão entre direito de família pessoal e patrimonial, limitando-se a seguir, passo a passo, a ordem de certos institutos. Agora, diversamente, o método de classificação, proposto por Clóvis do Couto e Silva, atendeu à análise interna, e não meramente a classificação extrínseca, das relações jurídicas de Direito de Família, atentandose á à concepção do "Direito como experiência', isto é, como "concretitude de valoraçãa do

\footnotetext{
${ }^{74}$ Neste sentido MAC-DONALD, Norberto da Costa Caruso, O Projeto de Código Civil e o Direito Comercial, cit., p. 153.

${ }^{2}$ A Consolidação das Leis do Trabalho, Decreto- Lei $n^{\circ} 5.452$, de $1^{\circ}$ de maio de 1943.
} 
Direito", como "realidade bistórico cultural"(..) atual e concretamente presente à consciência em geral, tanto em seus aspectos teoréticos como práticos" ${ }^{376}$, com o que afasta-se a concepção do Direito seja como objeto de contemplação ou descrição, ou, ainda, como "pura seqüência de esquemas lógicos ${ }^{377}$.

Ora, se a experiência juridica constirui a compreensão do Direito in actu, percebe-se que o Direito de Família - visualizado como totalidade e como complexo de valorações e comportamentos aos quais são atribuídos significados suscetiveis de valoração jurídica ${ }^{78}$ segundo certos valores morais e finalidades prálicas - compõe-se de elementos que " $n \tilde{a} o$ recebem e nem poderiam receber do ordenamento jurídico a mesma disciplina dos seus efeitos ${ }^{379}$. Percebe-se quase que intuitivamente que a sua normação, sobretudo no campo dos direitos pessoais, "é fortemente impregnada de princípios éticos, de tal modo que os próprios direitos lesados não se submetem aos mesmos cânones dos outros ramos do direito, como, por exemplo, o das obrigações ${ }^{\text {so }}$. Diversamente, o Direito Patrimonial de Família está informado pelos princípios gerais do Código, assumindo, por vezes, a estrutura de uma obrigação, submetendo-se, em outras, a regras que integram o Direito das Coisas ${ }^{81}$.

Por esta razão, e forte nestas concepções, alinhou-se, numa parte (Direito Pessoal) os aspectos mais propriamente existenciais, atinentes à dimensão do afeto, aí estando as regras relativas ao casamento, da dissolução da sociedade conjugal, da proteção à pessoa dos filhos, das relações de parentesco, da adoção e do poder familiar, expressão que, significativamente, substitui o "pátrio poder". Noutro Título está o Direito Patrimonial, englobando os direitos e deveres dos cônjuges, o regime de bens, a administração dos hens dos filhos, os interditos, o patrimônio familiar e as sociedades, provindo esta distinção do fato de "o ordenamento não poder deixar de valorizar as relaçóes dos partícipes da família levando em conta os seus atributos de pessoalidade e patrimonialidade já existentes na dimensão social's2.

\footnotetext{
${ }^{76}$ As expressōes grifadas são de REAl_E, Miguel, O Direito como Experiência, São Paulo, Saraiva, 1968, p. 31.

${ }^{77}$ Idem, ibidem.

${ }^{78}$. Neste sentido REALE, Miguel, op. por último citada, p. 31.

${ }^{79}$ COUTO e SIllVA, Clóvis, Exposição de Motivos para a Reforma do Direito de Família, in Anteprojeto do Código civil, Arquivos do Ministério da Justiça, vol. 155, Rio de Janeiro, 1975, p. 153.

str ldem, ibidem.

${ }^{81}$ Idem, ibidem.

\$2 COUTO e SILVA, Clóvis, Direito Patrimonial de Família no Projeto de Código Civil Brasileiro e no Direito Português, São Paulo, RT 520, 1979, p. 14.
} 
Pot intermédio desta metodologia, esclarece ainda Couto e Silva ${ }^{83}$, a revelação da existência de um duplo sistema de relações jurídicas no Direito de Famililia, permite que a diversidade material que está na sua base conduza à adoção de normas e de tutela jurídica valorativa e finalisticamente inconfundíveis, umas centradas na dimensão afetiva, pessoal, outra na dimensão propriamente patrimonial decorrente da sociedade familiar. Porém, como 'nem sempre uma relação jurídica aparece de modo puro, pessoal ou patrimonial", estando ambos os setores dialeticamente co-implicados, o critério lá de ser o da prevalência de um ou outto destes elementos, conforme a situação concretamente apreciada.

Assim, conquanto não rígida a classificação - como também não é rígida, no plano pré-jurídico, a distinção - o modelo adotado "torna mais compreensível o Direito de Familia porquellhe dá transparência, o quenem sempresuode quando se aglutinam numa sóffirura as mais diversas regras, submetidas, por força desta diversidade, a regimes jurídicos próprios ${ }^{\text {. }}$. Viabiliza, outrossim, compreender a diversidade de papéis que podem ser assumidos, no interior da estrutura familiar, pelos seus diversos figurantes, "conforme o seu círculo de atividades se insira no Direito Pessoal ou patrimonial".

A mesma estrutura pode ser observada, embora com menot apuro técnico, no Título III, telativo à União Estável, inserido pelo Congresso Nacional uma vez que a matéria constitui inovação proposta pela Constituição Federal de 1988, posterior, portanto, à elaboração do Anteprojeto. Mesmo sendo este Título III enxertado posteriormente - e talvez sem a clara consciência dos pressupostos filosóficos e culturais que conduziram à classificação contida nos Títulos I e II, observa-se, nos arts. 1.723 a 1.724 o regramento das relações pessoais entre os companheiros, sujeitas, portanto, à principiologia ali contida e também à cláusula getal da comunhão plena de vida, uma vez estar o casamento equiparado à união estável, por força constitucional. Já no att. 1725, estão as indicações relativas às relações patrimoniais, aqui mais fortemente sujeitas ao princípio da autonomia privada eà disciplina do Direito das Obrigações.

Completando a estrutura - que define o aspecto extemo do sistema - é à linguagem empregada pelo novo Código que devetemos agora atentat, pois esta indicará os aspectos internos do sisterna, o seu modelo, se aherto ou fechado. Tenho a convicção de aí residir a maior inovação da nova Lei, não se devendo buscar as "novidades" apenas em uma ou outra regra punctualmente arroladas, mas nos aspectos metodológicos, que poderão, se bem compreendidos e adequadamente utilizados, causar mudança realmente notável em relação ao Código de Beviláqua. Cahe, pois, pelo viés da linguagem, examinar a noção de sistema que está em seu substrato.

\footnotetext{
${ }^{83}$ COUTO e SILva, Clóvis, Direito Patrimonial de Família no Projeto de Código Civil Brasileiro e no Direito Português, cit., p. 15.

${ }^{84}$ Idem, ibidem.
} 


\section{B) A NOÇÃO DE SISTEMA QUE ACOLHE: O CÓDIGO COMO "EIXO CENTRAL" DOSISTEMA DE DIREITO PRIVADO ${ }^{85}$.}

Sabe-se que os grandes Códigos oitocentistas de que é paradigma o Code francês, foram construídos como sistemas fechados, isto é, o mais possível impermeáveis à intervenção da realidade e do poder criador da jurisprudência. Acreditava-se que a perfeição da construção conceitual e o encadeamento lógicodedutivo dos conceitos bastaria para a total apreensão da realidade nos lindes do corpus codificado. Em outras palavras, o modelo de Código oitocentista traduzia determinado modelo de sistema, constituindo, como já tive a ocasião de assinalar, verdadeiramente o "espelho e metáfora do sistema fechado" triburário das concepções iluministas, era dominado pela pretensão de plenitude lógica e completude legislativa. Surgiram assim, como um fenômeno típico da modernidade oitocentista, os Códigos totais, totalizadores e totalitários, aqueles que, pela interligação sistemática de regras casuísticas, tiveram a pretensão de cobrir a plenitude dos atos possíveis e dos comportamentos devidos na esfera privada, prevendo soluções às variadas questões da vida civil em um mesmo e único corpus legislativo, harmônico e perfeito em sua abstrata arquitetura.

A posição histótica do Código não tem, porém, caráter ahsoluto e imutável ${ }^{87}$, não podendo ser reduzida a uma noção, ou empobrecida pela rigidez de uma fórmula ${ }^{88}$ : a Codificação é um fenômeno histórico, é certo, mas a historicidade das formas jurídicas não é por si fixa e congclada no tempo. É correto pois, discernir entre o significado histórico da Codificação oitocentista - como fenômeno de ruptura que foi, como manifestação de uma determinada operação política, como instrumento de uma nova racionalidade, a do capitalismo, construído sobre a hegemonia de uma única classe social, a burguesia - e o significado que podem adquirir, na aurora do século XXI, os novos Códigos civis concretamente considerados, pois, de modo geral, nestes é diverso o relacionamento com as demais instâncias do todo social e com os diversos loci nos quais se manifesta o fenômeno jurídico, sendo, em conseqüência, tamhém diverso o modelo de sistema que espelham.

\footnotetext{
${ }^{85}$ Para as seguintes observaçöes sintetizei reflexões que expendi em "O Direito Privado como Construção: $A s$ Cláusulas Gerais no Projeto do Código Civil", citado, agregando algumas novas considerações.

Ba No nosso A Boa-Fé no Direito Privado, cit., P. 169.

87 Assim IRTI, Natalino, Códice Civile e Società Política, cit., p. 12.

sB Idem, p. 18.
} 
Os "Códigos totais", construídos ao modelo oitocentista, são marcados notadamente por sua linguagem, o mais "precisa" possivel. Diz-se que expressam um sistema fechado justamente porque, empregando a técnica da casuística, centrada em modelos cerrados, com a perfeita definição da fattispecie e de suas conseqüências, sua linguagem dificilmente permite comunicação com a tealidade que está em seu entomo, notadamente com os chamados "elementos metajurídicos", rais como valores éticos, dados econômicos, científicos, tecnológicos, elementos de ordem social etc. Por esta razão, para a regulação dos novos problemas, faz-se necessária a constante in tervenção legislativa.

Não é este, contudo, o modelo de sistema subjacente ao novo Código Civil, que adota diversos pressupostos metodológicos, atuando por intermédio de duas soluções técnicas: a primeira dela consiste num chamado à tesponsabilidade da jurisprudência, pelo emprego de numerosas cláusulas gerais; já a segunda diz respeito à tarefa do legisiador, encarregado, para o futuro, de editar "leis aditivas" ao Código, naqueles campos, como o Direito de Empresa e o Direito de Família, sujeitos à maior mutabilidade dos imperativos de ordem social e econômica, embora estejam estas futuras leis vinculadas ao Código, "eixo central", pela ligação ao valores e aos conceitos genéricos ali postos com a função de assegurar a unidade (relativa) do sistema.

\section{b.1) pressupostos metodológicos}

O Código Civil é polarizado, é certo, pela diretriz sistemática, que assegura a sua unidade lógica e conceitual, o que visa assegurar um minimum de segurança jurídica pela regulação coordenada dos comportamentos sociais desenvolvidos na esfera privada. Porém, do ponto de vista da técnica legislativa, o sistema caracteriza-se como um "eixo central 89 " e como um sistema aberto em virtude da linguagem que emprega, permitindo a constanre

\footnotetext{
日9 A expressão é de Clóvis do Couto e Silva, para indicar justamente o aspecto "não totalitário" do Código, mas a sua função de centro do sistema das relaçōes civis, necessariamente ligado ao que está às suas margens, isto é, tanto as "leis aditivas" quanto à realidade social, econômica e cultural. Por evidente, no centro do ordenamento está a Constituição, sabendo-se que a palayra "ordenamento" designa, como aponta Miguel REALE, uma espécie de "ecossistena" que abrange uma ampla variedade de sistemas e subsistemas normativos (ver, de COUTO e SlLVA, O Direito Civil Brasileiro em Perspectiva Histórica e Visão de Futuro, Porto Alegre, Revista Ajuris, v, 40, e de REALE, Fontes e Modelos do Direito - para um novo paradigma hermenêutico, São Paulo, Saraiva, 1994, p. 95).
} 
incorporação - e solução — de novos problemas ${ }^{90}$, seja por via da construção jurisprudencial, seja por ter a humildade de deixar ao legislador, no futuro, a tarefa de progressivamente complementá-lo.

Por isto é que sua inspiração por vezes aproxima-se estrutura constitucional, que requer leis complementares, bem como da sua linguagem, farta em modelos jurídicos abertos. Como já tive oportunidade de escrever, um Código não-totalitátio tem janelas abertas para a mobilidade da vida, pontes que o ligam a outros corpos normativos - mesmo os extrajurídicos - e avenidas, bem trilhadas, que o vinculam, dialeticamente, aos princípios e regtas constitucionais ${ }^{91}$.

Estas "janelas", bem denominadas por Irti de "concetti di collegamento" com a realidade social ${ }^{92}$ são constituídas pelas cláusulas gerais, técnica legislariva que conforma o meio hábil para permitir o ingresso, no ordenamento jurídico codificado, de princípios valorativos ainda não expressos legislativamente, de standards, arquétjpos exemplares de comportamento, de deveres de conduta não previstos legisiativamente ( $e$, por vezes, nos casos concretos, também não advindos da autonomia privada), de direitos e deveres configurados segundo os usos do tráfego jurídico, de diretivas econômicas, sociais e políticas, de normas, enfim, constantes de universos metajurídicos, viabilizando a sua sistematização e permanente tessistematização no ordenamento positivo.

Nas cláusulas gerais a formulação da hipótese legal é procedida mediante o emprego de conceitos cujos termos têm significados intencionalmente vagos e abertos, os chamados "conceitos jurídicos indeterminados". Por vezes - e aí encontraremos as cláusulas gerais propriamente ditas - o seu enunciado, ao invés de traçar punctualmente a hipótese e as suas conseqüências, é desenhado como uma vaga moldura, permitindo, pela vagueza semântica que caracteriza os seus termos, a incorporação de princípios e máximas de conduta originalmente estrangeiros ao corpus codificado, do que resulta, mediante a atividade de

\footnotetext{
${ }^{9}$ A propósito da perspectiva dicotômica entre "sistena" e "problema", observa REALE: "O direito todo estaria em causa, se pudesse prevalecer essa antinomia abstrata entre o "problemático" e o sistemático", só admissivel com base em um rígido e equívoco conceito de sistema". (In O Direito como Experiência, cit., p. 4). Por esta xazão vern a doutrina atentando ao "novo pensanento sistemático", como aludi in A Boa-Fé no Direito Privado, cit., p. 364.

${ }^{91}$ Assim o meu "O Direito Privado como Construção: As Cláusulas Gerais no Projeto do Código Civill", citado.

"2 IRT1, Natalino, Diritto Civile e Società Política, cit, P. 35.
} 
concreção destes princípios, diretrizes e máximas de conduta, a constante formulação de novas normas. Têm, assim, a vantagem da mobilidade proporcionada pela intencional imprecisão dos termos da fattispecie que contém, pelo que é afastado o risco do imobilismo porquanto é utilizado em grau míninıo o princípio da tipicidade ${ }^{9 / 3}$.

Dotadas que são de grande abertura semântica, não pretendem as cláusulas gerais dar, previamente, resposta a todos os problemas da realidade, uma vez que essas respostas são progressivamente construídas pela jurisprudência. Na verdade, por nada regulamentarem de modo completo e exaustivo, atuam tecnicamente como metanormas, cujo objetivo é remeter o juiz a critérios aplicativos determináveis ou em outros espaços do sistema ou mediante variáveis tipologias sociais, dos usos e costumes objetivamente vigorantes em determinada ambiência social. Em razão destas características essa técnica petmite capturar, em urna mesma hipótese, uma ampla variedade de casos cujas notas especificas serão formadas por via jurisprudencial, e não legal.

Desta constatação decorre que o juiz tem o dever, e a responsabilidade ${ }^{94}$, de formular, a cada caso, a estatuição, para o que deve percorter o ciclo do reenvio, buscando em outras normas do sistema ou em valores e padrões extra-sistemáticos os elementos que, motivando a decisão ${ }^{95}$, possam preencher e especificar a moldura vagamente desenhada na cláusula geral.

Conquanto tenha a cláusula geral a vantagem de criar aberturas do direito legislado à dinamicidade da vida social, tem, em contrapartida, a desvantagen de provocar - até que consolidada a jurisprudência - certa incerteza acerca da efetiva dimensão dos seus contornos.

${ }^{25}$ A tipicidade, pode ser compreendida como "a qualidade de uma pessoa, coisa ou conceito pela qual suas caracteristicas resultam conformes as de um tipo predeterminado", entendendo-se por "tipo" "o modelo ideal que reúne as características essenciais de todos os entes de igual natureza" (conforme Noeni Nidia Nicolau, "La autonomia de la voluntad como factor de resistencia a la tipicidad en el sistema de derecho privado argentino", Porto Alegre, nov. 1994, datilog.).

${ }^{24}$ A voz do juiz não é, todavia, arbitrária, mas vinculada. Como já se viu, as cláusulas gerais promovem o reenvio do intérprete/aplicador do direito a certas pautas de valoraçâo do caso concreto. Estas estão, ou já indicadas em outras disposiçöes normativas integrantes do sistema (caso tradicional de reenvio), ou são objetivamente vigentes no ambiente social em que o juiz opera (caso de direcionamento). A distinção deriva da circunstância de, em paralelo no primeiro e tradicional papel, estar sendo hoje em dia sublinhado o fato de as cláusulas gerais também configurarem normas de diretiva, assim concebidas aquelas que não se exaurem na indicação de um fim a perseguir, indicando certa medida de conportamento que o juiz deve concretizar em forma generalizante, isto é, com a função de uma tipologia social. Aí está posta, pois, uma das funções das cláusulas gerais, que é a de permitir a mobilidade externa do sistema.

95 Na concreção das cláusulas gexais cresce extraordinariamente o dever de fundamentar a decisão, devendo o juiz deixar claro năo só a concreta razāo de fato ensejadora da invocaçāo ao princípio, máxima de conduta ou ditetriz contidos na cláusula geral, como da conexão entre ambas, a razão de fato e a razāo jurídico-valorativa. Por isto, é imenso, nesta operação intelectiva, opeso dos precedentes judiclais, que expressam una espécie de "razâo comum" de decidir para os casos análogos ou similares. 
O problema da cláusula geral situa-se sempre no estabelecimento dos seus limites ${ }^{96}$. É por isto evidente que nenhum Código pode ser formulado apenas e tão somente com base em cláusulas gerais, porque, assim, o grau de certeza jurídica seria mínimo. Verifica-se, pois, com frequêencia, a combinação entre os métodos de regulamentação casuística e por cláusulas gerais, técnicas cuja distinção por vezes inclusive resta extremamente relativizada, podendo ocorter, numa mesma disposição, variados "graus" de casuísmo e de vagueza.

Assim acontece no novo Código Civil brasileiro, sobre o qual seu Relator no Senado Federal, Senador Josaphat Marinho, já nas primeiras linhas do Parecer pela aptovação assinalava: (...) o Projeto de Código Civil em elaboração no ocaso de um para o nascer de outro século, deve traduzir-se em fórmulas genéricas e flexiveis, em condiçôes de resistir ao embate de novas idéias' ${ }^{197}$.

Do mesmo modo, ao encaminhar o Anteprojeto à apreciação governamental, em 1975, sublinhava Miguel Reale a necessidade de a codificação do direito privado, nos dias atuais, aptesentar-se metodologicamente, mediante modelos abertos, expressos mediante uma "estrutura normativa concreta (...), destituida de qualquer apego a meros valores formais abstratos", o que seria alcançado se plasmadas, no Código, "soluções que deixam margem ao juiz è doutrina, com freqüente apelo a conceitos integradores da compreensão ética, tais como os de boa-fé, equïidade, probidade, finalidade social do direito, equizalência de prestaçãex, etc. ${ }^{\text {wog. }}$.

Por igual, outros integrantes da aludida Comissão, nomeadamente, José Carlos Moreira Alves e Clóvis do Couto e Silva, verberaram, em trabalhos acerca da proposta da nova lei civil, o caráter estruturalmente inovador de certas normas. Assim, Couto e Silva expressamente se manifestou:

"O pensamento que norteou a Comissão que elaborou o projeto do Código Civil brasileiro foi o de realizar um Código central, no sentido que lhe deu Arthur Steinwenter, sem a pretensão de nele incluir a totalidade das leis em vigor no País (...). O Código Civil, como Código central, é mais amplo que os códigos civis tradicionais. É que a linguagem é outra, e nela se contém "cláusulas gerais", um convite para uma atividade judicial mais criadora, destinada a complementar $o$ corpus juris vigente com novos princípios e normas". ${ }^{99}$

\footnotetext{
\% Nesse sentido a observação de Sérgio José Porto in A Responsabilidade Civil por Difamação no Direito Inglês, Ed. Sergio Fabris, Porto Alegre, 1995, p. 15.

${ }^{\prime \prime}$ Parecer Final ao Projeto do Código Civil, in O Projeto de Código Civil no Senado Federal, Vol. I, cit., p. 302 .

${ }_{98}$ Exposiçăo de Motivos do Projeto de Código Civil", 1975, in O Projeto de Código Civil - Situação atual e seus problemas fundamentais, cit., p. 84, grifos meus. No mesmo trabalho, averbou ainda conter o Código projetado preceitos "que, à primeira vista, podem parecer de mero valor ético, mas que, tendo como destinatírio primordial ojuiz, consubstanciam exigências de eqüidade, de amparo dos economicamente maisfracos, ou de preservação às forças criadoras do trabalho".

${ }^{9}$ COUTO E SU. VA, Clóvis, "O Direito Civil Brasileiro em Perspectiva Histórica e Visäo de Futuro" in Revista Ajuris no 40, Porto Alegrc, 1987, p. 128. O texto reproduzido está às páginas 148 e 149 .
} 
José Carlos Moreira Alves, por sua vez, há mais de uma década, alertava para o fato de a inserção das cláusulas gerais promover a mudança da concepção filosófica do novo Código pot meio de alterações formalmente diminutas, exemplificando com a concepção de propriedade, de tal maneira que, "com dois artigos apenas passou-se da propriedade individualista para a propriedade com função social"

Sendo este o pensamento dos autores do Anteprojeto, bem como o do Relator do Projeto no Senado, nada mais natural que o tex to venha a público pleno de cláusulas gerais. Estas situam o novo Código no plano da concretude, que constitui uma das dimensões da diretriz da operabilidade que norteou a sua redação.

A concretitude, ou concreção jurídica, significa "a correspondência adequada dos fatos às normas segundo o valor que se quer realizar" que tem o legislador de não legishar em abstrato, para um indivíduo perdido na estratosfera, mas, quanto possivel, legislar para o indivíduo situado" ${ }^{\text {OO2 }}$. É dimensão da operabilidade porque, viabilizando a "ética da situação" pela concreção dos modelos abertos, logra-se a constante alteração do significado e do conteúdo de uma disposição codificada sem alterar a sua letra, evitando, assim, os males da inflação legislativa e da rigidez que, matcando o modelo dos Códigos oitocentistas, ensejatam o seu distanciamento do "direito vivente".

Sabemos não ser uniforme o tecido das relações sociais, não se apresentando a sociedade como uma harmônica sinfonia de vozes promanadas por um abstrato sujeito de direito: hoje, à metáfota da sinfonia, substitui-se a da polifonia, por vezes mesmo a da cacofonia. Se na Codificação oitocentista a ficção da igualdade era o suporte ideológico dos próprios atributos das regras codificadas, quais sejam, a sua generalidade e abstração - a

${ }^{100}$ Orenra Alves, José Carlos, A Parte Geral do Projeto do Código Civil Brasileiro, cit., p. 27 ${ }^{10 t}$ Assim REALE, Miguel, O Projeto de Código Civil - Situação atual e seus problemas fundamentais, cit., p. 9.

102 Idern, P. 13.

10.3 REALE, Miguel, O Projeto do Novo Código Civil - situação após a aprovação pelo Senado Federal, São Paulo, Saraiva, 2000, p. 42. 
primeira designando "o caráter anônimo dos destinatários", a segunda "o caráter hipotético da ação disciplinada' ${ }^{104}$, hoje em dia esta ficção não mais remanesce nas normas agora codificadas, polatizadas que estão pela diretriz da concretude, à "ética da situação".

Esta expressão rica em significados indica, primariamente, que a noção de sujeito de direito deve ser percebida em sua essencial pluralidade, englobando tanto o rico quanto o pobre, o empresário e o desempregado, a grande corporação econômica e os menores de rua, o contratante forte e o contrarante débil, o latifundiário e o sem-terra, o consumidor e o fornecedor, enfim, o set humano e (m) suas circunstâncias, sempre urgentes e concretas. Deve-se considerar, ainda mais, que um mesmo sujeito pode desempenhar e desempenha, concomitantemente, vários papéis sociais. Por isso o apelo, tantas vezes feito na nova Lei Civil, aos "usos do lugar" às "circunstâncias do caso", à "natureza da situação"105, para permitir ao apljcador do Direito descer do plano das abstrações ao terreno por vezes áspero do concreto.

Os modelos abertos não estão uniformemente dispersos no novo Texto, e nem poderiam estar, pois é da natureza do Direito Civil conter campos que requerem maior ou menor ductilidade. A Parte Geral, destinando-se a "fixar os parâmetros de todo o sistema" - como afirmou José Carlos Moreira Alves - vem marcada pelo propósito "de máximo rigor conceitual "106 . Abriga, mesmo assim, ponderável númeto de normas abertas ou semanticamente vagas, inclusive fazendo remissão a princípios ou direcionando o juiz à pesquisa de elementos culturais, econômicos e sociais, sendo aí potencialmente forte o impacto do princípio constitucional da dignidade da pessoa humana.

Ainda assim, e no que concerne especialmente ao Direitos de Personalidade, tratados na Parre Geral, penso que o novo Código poderia ainda ter avançado nesta matéria, talvez pelo emprego de uma cláusula geral do Direito de Personalidade, a exemplo do que procedeu relativamente a um dos seus aspectos, qual seja, o direito ao resguardo da vida privada. Criaria assim, mais diretamente, uma ponte entre o princípio constitucional da dignidade $\mathrm{da}$ pessoa e os direitos constitucionais sociais, também atinentes à múltipla dimensão da personalidade, sendo indiscutivel que a atual ênfase numa esfera de valores existenciais da pessoa deve-se, entre outros fatores, à compreensão do papel desempenhado pelos princípios constitucionais no Direiro Civil. Estes, para além de constituírem normas jurídicas atuantes nas relações de Direito Público, rêm incidência especial em todo o ordenamento e, nesta perspectiva, também no Direito Civil, disciplina das relaçôes jurídicas travadas entre os

\footnotetext{
104 As expressões en itálico são de IRTI, Natalino, Diritto Civile e Società Polírica, cit., p. 25.

to V.g, os artigos $111,113,128,326,427,429,569,596,597,615,695,699,700,724$ etc.

$10 *$ MOREIRA AlveS, José Catlos, A Parte Geral do Projeto do Código Civil Brasileiro, cit., p. 7.
} 
particulates entre $\mathrm{si}^{\mathrm{i} 07}$. Todavia, pelo viés da tutela dos danos à pessoa, como examinarei em seguida ${ }^{108}$, esta ligação resta marcada, viabilizando alargado campo de tutela, inclusive preventiva.

Esta tutela preventiva não resta, porém, suficientemente clara no que diz com a indevida utilização da imagem (art. 20), objeto de proteção indenizatória. É certo que, para além da tutela indenizatória, uma tutela preventiva da imagem é absolutamente necessátia num tempo em que a indústria do marketing conduz à derisão os valores do pudor pessoal e da intimidade, em que o totalitatismo das empresas de comunicação tudo transforma em matéria de sua ganância. Assim, uma cláusula getal de proteção à imagem, juntamente com a norma dos arts. 12 e 21, antes aludidas, e outta telativa ao Direito Geral da Personalidade, certamente ensejariam maiot facilidade no trânsito, às relações civis, dos valores constitucionais fundamentais ${ }^{109}$, notadamente os que têm por objeto a tutela do que Miguel Reale, desde aos anos 40, tem denominado de "valor-fonte" do ordenamento - a pessoa bumana considerada em sua própria fundamental dignidade ${ }^{110}$, alcançando mais facilmente o desenvolvimento jurisprudencial de novas bipóteses.

Contudo, mesmo não explicitando o Código esta previsão, é possível chegat, por via jurisprudencial, à construção de um de um "Direito Geral da Personalidade" que não se esgota no reconhecimento dos tradicionais atributos, tais como a honta, o nome, a imagem, a intimidade e a vida privada, mas que tem alargada possibilidade de contínua expansão. É que aqui, o "progresso" do Direito, para reconhecer continuamente 'novos direitos de

${ }^{m}$ Como referência a esta a questão, consulte-se Pietro PERLINGIERI, Il Diritro Civile nella legalirà costituzionale", Nápoles, Edizione Scientifiche Italiane, 1991, Joaquin ARCE Y FLORES-VALDEZ, El Derecho Civil Constitucional, Madrid, Civitas, 1986; Konrad HESSE, Derecho Constirucional y Derecho Privado, Madrid, Civitas, 1985. Na literatuza brasileira, Maxia Celina BODIN DE MORAES, "A caminho do Direito Civil-Constizucional", Revista Direito, Estado e Sociedade, PUC, Rio de Janeiro, 1991, p. 59, Tetesa NEGREIROS, Fundamentos para uma interpretação constitucional do princípio da boa-fé, Rio de Janeiro, Renovar, 1998, Luis Afonso HECK, "Direitos Fundamentais e sua influência no Direito Civil", in Revista da Faculdade de Direito da UFRGS, vol. 16, Porto Alegre, 1999, p.111 e Luiz Edson FACHIN, Teoria Crítica do Direito Civil, cit.

${ }^{10}$ Vide item b. 2 - um caso exemplar de "abertura e mobilidade"do sistema: os danos à pessoa.

tos A Constituição Brasileira insere, no inciso IrI do art. $1^{\circ}$, a dignidade da pessoa humana entre os valores fundamentais da República, tratando, no art. $5^{\circ}$, dos direitos fundamentais indiviciuais, entre os quais estão a proteção da vida, da saúde, da honra, da imagem, da vida privada e da intimidade das pessoas.

${ }^{\text {ito }}$ Como anotei em outro ensaio - "Direito e Cultura - Entre as Veredas da Existência e da História "-o valor da pessoa humana como "valor fonte de todos os valores" ou "valor fonte do ordenamento" tem sido objeto da atenção de REALE desde os seus primeiros escritos filosóficos, ainda na década de 40, sendo versado já em Fundamentos do Direito ( primeira edição, 1940, terceira edição, São Paulo, Revista dos Tribunais, 1998). Porém, é em Pluralismo e Liberdade (Rio de Janeiro, Expressão e Cultura, 1998 ( $2^{a}$ edição, $1^{a}$ edição 1963) que assentará con todas as letras que o "problema central da axiologia juridica, vista em função da experiência histórica, é o relativo ao valor da pessoa humana", ali produzindo, notadamente no Capítulo V, notáveis ensaios. 
personalidade", é tarefa que resulta da concreção, no campo das relaçốes interprivadas, do já aludido princípio constitucional da dignidade da pessoa humana por intermédio de sua ligação intersistemática com os demais princípios e regras do Código, competindo, pois, à jurisprudência, construír a sua dogmática, com bases nestes fundamentos axiológicos e normativos, e de acordo às necessiddades práticas que se apresentarão no decurso do tempo.

Como exemplo da possibilidade de reconstrução sistemática ensejada pelo novo Código tomo o caso dos danos à pessoa, espécie do gênero danos extrapatrimoniais, pois aí é nítida a conexão intersistemática (entre diversos sistemas ou subsistemas integrantes de um mesmo ordenamento) e intrassistemática (entre normas integrantes de um mesmo sistema, ou subsistema).

\section{b.2) Um caso exemplar de "abertura e mobilidade"do sistema: os danos à pessoa.}

O modelo paradigmático de ligação intersistemática é o que ocorre entre a Constituição e o Código Civil, avultando aí em importância especial para o Direito Privado o princípio constitucional da dignidade da pessoa humana.

Vazado em termos amplíssimo e incidente em todo o ordenamento, espraiando-se por todos os "ramos' do Direito, o princípio da dignidade da pessoa humana deve ser densificado, tornando-se concreto e operativo em particulares domínios de casos. O campo dos danos à pessoa é exemplar, pela excelência do tratamento dado pelo novo Código ao instituto da responsabilidade civil. Conectando-se este instiruto ao princípio constitucional às cláusulas gerais e regras objeto do novo Código, e ainda operando-se a ligação com instrumentos de índole processual, poderá ser viabilizada a permanente e crescente reconstrução do modelo jurídico ${ }^{\mathrm{it1}}$ da responsabilidade civil por danos à pessoa, ou danos aos direitos de personalidade.

Para tanto, é necessário estabelecer conexão entre as normas do art. $5^{\circ}$, incisus Ve X constitucional, as cláusulas gerais dos arts.12,21, 187 e as regras dos arts 927 e seu parágrafo único e 944 do novo Código Civil e ainda, se for o caso, das regras dos artigos 287, 644 e 645

"Acerca da acepção pela qual tomo a expressão "modelo jurídico", REALE, Miguel, Fonres e Modelos..., cit,, meu ensaio acerca da "Boa-Fé como Modelo", in Diretrizes Té́ricas do Novo Código Civil, MARTins COSTA, J. e BRANCO, G., no prelo. 
do Código de Processo Civil ${ }^{12}$ ou, havendo telação de consumo, do art. 84, caput, do Código de Defesa do Consumidor.

Como já se viu, consoante o art. 12 , pode-se "exigir que cesse a ameaça ou a lesão a direito de personalidade, e reclamar perdas e danos sem prejuizo de outras sanções previstas em le $i^{113}$ ", sendo de observar que no suporte fático desta norma está não apenas o dano já consumado, mas também a ameaça de dano a direito da personalidade, o que introduz, no instituto da responsabilidade civil, um nítido caráter preventivo. Isto porque, para impedir o dano, a continuidade dos seus efeitos ou mesmo a sua mera possibilidade, a norma oferece, diante da ameaça, tanto a solução ex post, qual seja, o pagamento de perdas e danos, como recursos de ordem preventiva, tais como, por exemplo, a imposição de obtigação de não-fazer ao autor da ameaça, podendo o determinat, se descumprida a obrigação, o pagamento de astreintes.

Se o arentado for a um específico direito de personalidade, qual seja, a vida privada, é chamada a operar a cláusula geral do arr. 21 . Aqui também se está a indicar que o juiz tem o dever de determinat a providência que, à vista das circunstâncias, entenda mais adequada à otimização do conteúdo da norma protetiva, desde que a busque no quadio das soluções técnicas oferecidas pelo ordenamento.

Pot evidente, estas cláusulas gerais, constitucionais e civis, de proteção à pessoa estão ligadas ao novo regime dos atos ilícitos, seja ao disposto no art. 186 - cláusula geral de responsabilidade, patrimonial ou extraparrimonial, por culpa - seja à cláusula geral de ilicitude do art. 187, que é, como antes assinalei, de índole objetiva, pois não requer ato culposo para situar no plano da ilicitude o ato ptaticado abusivamente, ou desviado de seu fín econômico ou social, ou excedente dos limites traçados pela boa-fé e pelos bons costumes $^{114}$.

\footnotetext{
t12 Como alerta Araken de ASSIS en comentário ao art. 644 do CPC, hoje em dia, "desaparecido o rito especial da vetusta aça cominatória, há nova sistemática na aplicação do preceito (ordem, monitónio, mandado). A pressão psicológica sobme o devedor, derivada da astreinte, doravante ocorre após o provimento judicial (sentença ou decisão liminar, exvido art. 461, $\$ 3^{\circ}$.) e o esgotamento do prazo de cumprimento assinado na forma do art. 632 ". Muito embora a aplicação da pena deva constar do pedido (art. 287), "ao juiz se mostrarálícito, no caso de omissão, impor multa independentemente do pedido (art. 461, $\left.\$ 4^{\circ}\right)$." Em suma, "a cominação passon à órbita dos poderes do juiz, que não se vincula, neste assunto, à iniciatiza da parte". (Comentários ao Código de Processo Civil, vol IV, arts. 566 a 645, Rio de Janeiro, Forense, $1^{2}$ edição, $4^{2}$ tixagheın, 2001, p. 424).

"11. Grifos meus.

${ }^{114}$ Art 187: "Comete ato ilícito o titular de um direito que, ao exercêlo, excede manifestamente os limites impostos pelo sen fim econômica-social, pela bra-féou pelos bons costumes".
} 
Maior será o alcance se o princípio constitucional e ambas cláusulas getais acima indicadas forem ligadas às normas que defluem do art. 927 , que estabelece a obrigação de indenizar o dano causado por ato ilícito.

No seu parágrafo único, o Código instirui espécie de cláusula geral de responsabilidade objetiva, ao determinar o nascimento do dever de indenizar, independentemente de culpa, não apenas nos casos especificados em lei, mas também "quando a atividadenormalmentedesenvolvida pelo autordo dano implicar, porsua natuncza, risco para os direitos de outrem". No substrato desta norma está a noção de estrutura social, tão cara à Miguel Reale, entendendo-se por esta noção " $u m$ todo de valoraçôes, determinado pela polarização de uma valorafão-matriz", incompreensivel "em termos de mera causalidade, ou de puras relações formais" $"$.

Assirn é que, transposta ao plano da dogmática da responsabilidade civil, esta noção pennite afirmar: "Se aquele que atua na vida jurídica desencadeia uma estrutura social que, por sua própria natureza, écapaz de por em riscos os interesses e os direitos allheios, asua responsabilidade passa a ser objetiva e não mais apenas subjetiva" ${ }^{\text {"16 }}$. Em outras palavras, é a noção metajurídica de "atividade normalmente exercida pelo autor do dano, que implique risco", a ser necessariamente concretizada pelo intérprete, que definirá qual o regime aplicável à responsabilidade, constituindo esta norma ao meu ver, a projeção, neste domínio, da diretriz da solidariedade social.

Por evidente, e no que toca à indenização, as normas do art. 927 e seu parágrafo devem ser ainda conjugadas com a do art. 944, segundo o qual a indenização mede-se pela extensão do dano, cabendo ao juiz, no caso de desproporção entre a gravidade da culpa e o dano, reduzir "eqüitativamente" a indenização: trata-se ai da concreção, no campo da responsabilidade civil, do princípio da proporcionalidade que domina o ordenamento jurídico em sua integralidade, apresentando-se mais propriamente como dever de proporcionalidade ${ }^{117}$.

\footnotetext{
${ }^{115}$ REALE, Miguel, O Direito como Experiência, cit., p. 156.

${ }^{116}$ RENLE, Miguel, O Projeto de Código Civil - Situação Atual e seus Problemas Fundamentais, cit., $\mathrm{P}, 10$.

117 Veja-se, a propósito, o excelente estudo de AVILA, Humberto Bergmann, $A$ Distinçáo entre Princípiose Regras e a Redefinição do Dever de Proporcionalidade, Revista da Pós"Graduaçăo da Faculdade de Direito da USP, 1, 1999, Porto Alegre, Síntese, 1999, p. 27, no qual explica: "O dever de proporcionalidade não é um princípio ou uma norma-princípio (...). Este, na verdade, "estabelece uma estrutura formal de aplicaţão dos princípios envolvidos: o meio escolbido deve ser adequado, necessário e não excessizo. (...) Por isto, "consiste num postulado normativo-aplicativo", "consiste numa condição normativa, isto é, instituída pelo próprio Direito para a sua devida aplicação". (Pp. 46 a 49 , grifos do autor).
} 
Por esta razão estou convencida de que o Poder Judiciário, utilizando responsavelmente ${ }^{118}$ as cláusulas gerais dos artigos 186 e 187 poderá promover alargada construção do direito dos danos, cujas conseqüências estão previstas na Parte Especial (art.389 e seguintes, art.402 e seguintes, art. 927 a 954). Poderá, ainda, se combinar adequadamente estas previsões abertas com outras contidas na Parte Geral (v.g., a da tutela à vida privada) ou em outras leis (por exemplo, o Código de Processo Civil, ao prever formas de tutela inibitória), proceder ao progresso do Direito à vista de situações ainda não previstas pelo legislador, sem a necessidade de recorrer à pontual intervenção do legislador, amenizando, assim, os males da inflação legislativa.

Já por este exemplo fácil é perceber no que consiste a "abertura e a mobilidade" de um sistema que é e deve ser complexo, e não aplasmador, simplificante, justamente porque tem que levar em conra o ser humano concreto, o dano concreto, as circunstâncias concretas em que opera ou pode operar o prejuizo ou a ameaça de prejuízo, tudo permeado pelo valor fundamental da tutela à pessoa. Percebe-se, então, a razão pela qual o conceito de estrutura que está na base do aludído parágrafo único do art. 927 "éinseparável de sua compreensão axiológica, isto é, do elemento significativo ou compreensivo (...)"119 que está na raiz do procedimento hermenêutico.

Outro exemplo da incidência, ao novo Código, de disposições principiológicas constitucionais está na proteção ao nascituro: na Parte Geral (arts. $1^{\circ}$ a 232), entre as disposições gerais aplicáveis às pessoas, aos valores essenciais da personalidade humana, do regramento das pessoas jurídicas, dos bens e dos fatos juridicos, encontramos a regra relativa à personalização civil, iniciada do nascimento com vida, protegendo-se os direitos do nascituro desde a concepção ${ }^{120}$. Para interpretá-la numa perspectiva não patrimonialista, mas garantidora da perspectiva existencial da vida humana, bastará vincular a esta regra o caput do art. $5^{\circ}$ da Constituição, que protege o direito à vida, alcançando-se, assim, a proteção extrapatrimomal ao nascituro, não mais limitando-se, pois, esta tutela, aos aspectos exclusivamente patrimoniais, consoante já acenou pioneita jurisprudência do Tribunal de Alçada do Rio Grande do Sul ${ }^{21}$.

\footnotetext{
${ }^{11 \beta}$ Acerca da utilização, pelo Judiciário, das cłáusulas gerais, seus limites e responsabilidades, veja-se AGUIAR JUNNIOR, Ruy Rosado, "O Poder Judiciário e a concretizaf̧ão das cláusulas gerais: limites e responsabilidades" , Revista da Faculdade de Direito da UFRGS, vol. 18, Porto Alegre, 2000, p.221.

119 RE $A$ LE, Miguel, O Direito como Experiência, cit, p. 157, grifos do autor.

${ }^{120}$ Ast 2 " $A$ personalidade civil da pessa comera do nascimento com vida" mas a lei póe a sal $w$, desde a concep $x \tilde{a} 0$, os direitos do nascituro".

${ }^{221}$ Ap. Civ. n $195080585,5^{2}$ C. Civ., 26.10.95, Rel. Des. Rui PORTANOVA, in RTARGS 97/298.
} 
A "abertura e mobilidade"do sistema caracteriza-se, pois, pela conjugação que o Código viabiliza entre cláusulas gerais e regras específicas, ocortendo setores, como, exemplificativamente, o Direito da Empresa, em que ocorre uma normativa genérica, assecutatótia de uma certa unidade conceitual e valorativa, a ser completada, contudo, por leis aditivas, especificantes, em matérias sujeitas ao mais intenso dinamismo econômico-social, de determinados regulamentos particulares.

É nos Livros concernentes ao Direiro de Família, ao Direito das Obrigaçōes e aos Direitos Reais que encontraremos, em paralelo às normas marcadas pela estrita casuística, a maior parte das cláusulas gerais, as quais todavia permeiam, ainda que mais escassamente, os demais Livros. O seu exame proporcionará uma visão do conteúdo do novo Código e de suas diretrizes fundamentais.

\section{II) O CONTEÚDO DO NOVO CÓDIGO EM SUAS DIRETRIZES FUNDAMENTAIS}

Consoante adverte Miguel Reale, a afirmação corrente de que uma lei não deve ser interpretada segundo a sua letra mas consoante o seu espírito leva a considerar o conjunto de diretrizes que norteou a obra codificadora "constituindo o seu travamento lógico e técnico, bem como a base de sua fundamentação ética" "122. Arrola, assim, quatro diretrizes, a saber: a da sistematicidade, a da operabilidade,a da eticidade e a da socialidade. Já examinadas, na apresentação da estrutura e do sistema, as duas primeiras, analisatei as direrrizes da eticidade (A) e da socialidade (B) que poderão dar uma ampla visão do conteúdo do novel Código Civil.

Ambas, eticidade e socialidade, constituem perspectivas reversamente conexas, pois as regras dotadas de alto conteúdo social são fundamentalmente éticas, assim como as normas éticas têm afinidade com a socialidade. A distinção ora procedida, de cunho meramente pedagógico, não faz mais do que assinalar ênfases, ora pendendo para o fundamento axiológico das normas, ora inclinando-se às suas características numa sociedade que renta ultrapassar o individualismo, não significando, de modo algum, que uma regra ética não se ponha, também, na dimensão da socialidade, e vice-versa.

\footnotetext{
${ }^{122}$ REALE, Miguel, O Projeto de Código Civil - Situação arual e seus problemas fundamentais, cit., p. 3.
} 


\section{A) A ETICIDADE COMO FUNDAMENTO DAS NORMAS CIVIS.}

As regras jurídicas jamais são um "dado", antes constituindo um "construído" por realizarem-se sempre na História, consubstanciando, assim, uma das privilegiadas dimensöes da cultura. Se esta afirmação é correta para o Direito em sua integralidade, sua adequação ressalta particularmente no Direito Civil, que é o Direito das pessoas que vivem na cive, traçando as regras aplicáveis às pessoas enquanto pessoas, dos "bomens enquanto bomens" 13 os quais relacionam-se, no entanto, em necessária comunidade. Bem por isso hoje o Direito Privado reapresenta-se como "direito sim dos particulares, mas dos particulares uti cives; direito dos particulares como portadores da sua própria singularidade, mas também da necessidade de comunicá-la aos outros; da necessidade de isolar-se (que é algo a ser respeitado) mas também de associar.se; da necessidade de defender a própria personalidade, mas também de desen wolvêlla na comunidade que a enriguece e não a comprime", como afimou, magnificamente, Giorgio Oppo ${ }^{124}$. Direito dos particulares, do que é, pois de interesse particular na tríplice dimensão do ser (direitos da personalidade, direito pessoal de família) do ter (direito de propriedade) e do agir (direito das obrigações, dos contratos e da empresa), mas que nem por isso se contrapõe ao que é interesse público, pois direito dos particulares que vivem na ordem civil.

O conteúdo do Direiro Privado, bem por isto, está muito proximamente ligado ao valor que historicamente é dado à pessoa e às suas relações com os demais bens da vida, patrimoniais ou existenciais, com as esferas do ser, do ter e do agir. Se o mais relevante for a relação entre a pessoa e os bens patrimoniais, economicamente avaliáveis, crescem em importância as regras jurídicas atinentes à tutela do patrimônio. As normas do Direito Privado restam aí reduzidas a meios de tutela dos bens patrimoniais, obscurecendo-se a civilidade, dimensão social da existência, e a própria dimensão social do "ser civil" no individualismo egoísta.

Contudo, se em primciro plano está a pessoa humana valorada por si só, pelo exclusivo fato de ser pessoa - isto é, a pessoa em sua irredutível subjetividade e dignidade, dotada de petsonalidade singular e por isto mesmo titular de atributos e de interesses não mensuráveís economicamente - passa o Direiro a construir princípios e regras que visam tutelar essa dimensão existencial, na qual, mais do que tudo, ressalta a dimensão ética das normas jurídicas. Então o Direito Civil reassume

${ }^{123}$ Assim a proposiçăo de HOBBES em De Cive (Do Cidadão). Tradução de Renato Janine Ribeiro. São Paulo, Martins Fontes, p.10.

12. OPPO, Giongio, "Diritto Privato e Interessi Pubblici", in Rivista di Diritto Civile, 1994, 1, p.26, traduzi. 
a sua direção etimológica e, do direito dos indivíduos, passa a ser considerado o direito dos civis, dos que portam em si os valores da civilidade.

Ora, sendo o Coordenador da Comissão Elaboradora do Projeto um filósofo e humanista do porte de Miguel Reale, é narural que o seu texto encontre-se permeado por regras nas quais é funda a exigência de eticidade que deve pautar as relações extrapatrimoniais e patrimoniais entre as pessoas, portadoras que são da especial dignidade que, agora, a própria Consrituição Federal thes reconhece. Por isso, afirma Reale, o novo Código, diferentemente do Código de 1916, "muito avaro ao referir-se à equidade, à boa-fé, à probidade", é, "ao contrário, pródigo em inserir, nos mais diversos aspectos das relações civis, a exigência da eticidade nas condutas, como um verdadeiro dever jurídico positivo." 25

Em vários artigos pode-se observar, como uma das mais salientes características do novo Texto Civil, a valorização dos pressupostos éticos na ação dos sujeitos de direito, seja como conseqüência da proteção da confiança que deve existir como condição sine qua non da vida civil, seja como mandamento de eqüidade, seja, ainda, como dever de proporcionalidade.

O princípio da confiança vem especificado, no interior das relações que nascem do tráfego jurídico, notadamente (mas não exclusivamente) o tráfego negocial, pelos correlatos e conexos princípios da lealdade e da boa-fé objetiva, ambos constituindo a dupla face da confiança. Estes princípios têm a característica de constituir normas de conduta que impõem a quantos entram em contacto social relevante juridicamente deveres de conduta, entre os quais os de informação e os de proteção aos legítimos interesses do alter.

A correlação entre a lealdade e a boa-fé está em que esta última, na acepção objetiva, caracteriza arquétipo ou standard jurídico, segundo o qual cada pessoa deve ajustar a própria conduta a esse arquétipo, obrando como obraria um homem reto: com honestidade, lealdade, probidade, qualificando, por isto, uma norma de comportamento leal ${ }^{126}$. A boa-fé objetiva vem posta como princípio cardeal do moderno Direito das Obrigações, sejam estas civis ou comerciais, como emanação da confiança que deve presidir o tráfico jurídico, entendendo Mário Júlio de Almeida Costa que

"As exigências pragmáticas do tráfico jurídico e uma legítima aspiração a um direito objectivamente justo postulam que não se atenda apenas à intenção ou vontade do declarante, mas também à sua conduta è confiança do destinatário" ${ }^{27}$.

Para além de designar, em sua acepção objetiva, uma norma de conduta que impõe aos participantes da relação obrigacional um agir paurado pela lealdade, pela colaboração

\footnotetext{
'25 REALE, Miguel, O Projeto de Código Civil - Situação atual e seus problemas fundamentais, cit., p.8.

126 Assim o nosso Da Boa-Fé no Direito Privado, São Paulo, Revista dos Tribunais, 1999, p. 411. ${ }^{127}$ ALMEIDA COSTA, Mario Júlio Responsabilidade civil pela ruptura das negociaçôes preparatórias de um contrato, Coimbra, Coimbra Ed., 1984, p 48, grifei.
} 
intersubjetiva no tráfico negocial, pela consideração dos interesses da contraparte, o princípio da boa-fé indica, outrossim, um critério de interpretação dos negócios jurídicos e uma norma impositiva de limites ao exercício de direitos subjetivos, em certas hipóteses. Como emanação da confiança no domínio das obrigações, a grande relevância dos deveres que decorrem da lealdade e da boa-fé objetiva está em que, como norma de conduta, operam defensiva e ativamente ${ }^{128}$, isto é, impedindo o exercício de prerensões e criando deveres específicos ${ }^{129}$ que decorrem do dever geral de colaboração que domina todo o Direito das Obrigações.

O novo Código, pródigo nas referências ao princípio, seja nas sua acepção objetiva, como tegra de conduta, seja na versão subjetrva, designativa de uma ctença na apatência de ilicitude ou da conviç̧ão de não se estar a lesar direito alheio, engloba uma verdadeira exigencia de comportamento correto, probo e leal na vida de relações sociais. Nesse sentido os já aludidos arts. 113, impositivo do standard da boa-fé na interpretação dos negócios jurídicos, 128 , elusivo da eficácia de condição resolutiva sobre atos já praticados, em negócios de execução continuada ou periódica, se conformes estes à boa-fé objetiva, e 187, atributivo de ilicitude ao ato se exercitado o direito $\mathrm{em}$ desconformidade à conduta segundo a boa-fé.

Não aí se esgotam, contudo, as referências à boa-fé: é no campo do Direito Obrigacional que encontraremos as mais vigorosas referências a esta norma impositiva de conduta leal, geradora de um dever geral de correção que domina o tráfego negocial.

Desde logo, a boa-fé vem posta como princípio fundamental e cláusula geral dos contratos (art. 422), seja na fase de sua conclusão (abrangendo, por óbvio, a fase das tratativas, pois se deve considerar a noção da obrigação como um processo ${ }^{130}$ ), seja na sua execução. Nas relações contratuais, o que se exige é uma atitude positiva de cooperação, e, assim sendo, o princípio é a fonte normativa de deveres de comportamento pautado por um específico standard ou arquétipo, qual seja a conduta segundo a boa-fé que reveste todo o iter contratual.

Assim, conquanto não esteja expresso na littera do Código o dever de ser observada a conduta segundo a boa-fé também na fase das tratativas negociais, e, quando for o caso, no petiodo pós-contratual, há de ser compreendida a sua extensão tamhém a esses periodos, em razão da própria natureza de cláusula geral que reveste $o$ art. 422 e ao cunbo eminentemente prospectivo que está no cerne desta técnica legisiativa.

${ }^{128}$ COUTO E SILVA, Clóvis, "O princípio da boafé no Direito brasileiro e português", in Estudos de Direito Civil Brasileiro e Português, São Paulo, 1986, p. 55.

${ }^{129}$ No mesmo sentido, o meu A Boa-Fé no Direito Privado, cit., pp. 427 e ss.

${ }^{131}$ A idéia da obrigação como um processo que liga os seus partícipes e se dirige à sua finalidade, que ć o adimplemento, atravessando as fases das tratativas, quando existentes, da conclusão (formação contratual), desenvolvimento e adimplemento, podendo projetar-se inclusive para o petiodo pós-contratual, for desenvolvida por um dos codificadores, Clóvis do COUTO E SILVA, encontrando-se expressa na própria estrutura do Direito Obrigacional no Projeto. (Vide do autor A Obrigação como Processo, São Paulo, José Bushatsky, 1976) 
Constituindo cláusula geral, o art. 422 também acolhe, em outro exemplo, o princípio que veda venire contra factum proprium. Este incide, por certo, na fase da execução contratual, e também no âmbito do contrato preliminar, que passa agora a ser regulado no próprio Código (arts. 462 a 466), mas que adquire particular relevância no período pré-contratual, no qual se desenvolvem as chamadas "negociações preliminares". Os variados contratos que disciplinam, sempre mais freqüentemente, vastos projetos nas áreas financeira, comercial ou industrial, têm necessidade, pela complexidade que lhes é ínsita, de longas atividades preparatórias, tendo a praxe negocial, ainda antes da elaboração teórica, criado um "sistema de contratação" que retoma, atualizando-os, os antigos conceitos de minuta e punctação, inserindo-os na chamada formação progressiva do acordo. As letters of intent, os beads of agreement, as instructions to proceed, os "acordos de base", os memorandos de entendimento e todas as restantes declarações de intenção de contratar - práticas que não apresentam descrição homogênea e são, por vezes, de difícil qualificação jurídica — constituem os produtos desta realidade, atestando a importância que rem crescentemente revestido a fase antecedente do contraro.

Ora, nesta fase em que estão as partes ainda não formalmente vinculadas a obrigações propriamente contratuais, o princípio que veda "venire contra factum proprium 131 " se apresenta com particular relevância porque, traduz justamente o princípio geral que tem como injurídico o aproveitamento de situações prejudiciais ao alter para a caracterização das quais tenha agido, positiva ou negativamente, o titular do direito ou faculdade ${ }^{132}$.

Em modo genérico se pode afirmar que recai na proibição do venire quem, tendo estabelecido determinados critérios, ou agido segundo determinada direção, modifica de critério, ou altera a direção seguida, em prejuízo alheio. Indica a expressão venire contra

137 Veja-se, a propósito, BORDA, Alejandro, "La Teoria de los Actos Proprios", Buenos Aires, Abeledo.Perrot, $3^{*}$ edição atualizada e ampliada, 2000, p. 13

${ }^{1.32}$ Assim o meu Da Boa-fé no Direito Privado, cit., p. 462. 
factum proprium, por igual, um freio erguido à pretensão de quem reclama algo em aberta contradição com o que havia anteriormente aceitado, como explica Moisset de Espanés ${ }^{133}$, podendo ainda ser catacterizada por uma omissão, quando tinha o agente, para manter comportamento coerente com sua ação anterior, o dever de agir. Entre tantos exemplos que aqui poderiam ser indicados está a omissão em adotar providências tendentes a garantit o adequado adimplemento do pactuado, ou do combinado na fase pré-contratual ou, ainda, a omissão de informar ao parceiro contratual, ou pré-contratual, acerca de certo requisito de forma, para, após, requerer, por este motivo, a resolução ou nulidade do pactuado, ou assim justificar o seu recesso das tratativas negociais. Abarca ainda o venire casos nos quais verificase a omissão, por parte de um parceiro contratual ou pré-contratual, em informar adequadamente a contraparte acerca de pontos que seriam essências à perfeita formação do consentimento, para vir $o$ autor do ato ${ }^{134}$ posteriormente, buscar esquivar-se à realização do combinado, "justificando" o eventual pedido anularório, ou resolutório, ou a sua retirada das negociações, justamente pela ausência de providências que teriam sido adotadas pela contraparte, se devidamente informada.

Está a boa-fé, seja em sua feição subjetiva, scja objetiva, ainda prevista em expressivas referências tópicas na disciplina das espécies contratuais $(v . g$, o art. 518 , a contrario, em maréria de preempção, na compra e venda; art. 523, na venda com reserva de domínio; arts. 686 e 689 , no contrato de mandato), sendo ainda expressamente aludida em matéria de atos umlaterais, como a promessa de recmpensa (art. $856, \$$ único) e no que diz com as regras relativas ao pagamento (arts. $879 \mathrm{e} \$$ único).

A boa-fé também está aludida nos arts 765,766 , a contrario, concernentes ao seguro. Neste campo a boa-fé é verdadeiramente multidimensional, pois atua subjetivamente, como "crença", impõe o dever de veracidade às partes, como decorrência da lealdade, e o dever de consideração, pelo segurado, aos interesses da contraparte, no art. 768 , vedando-lhe a prática de atos que agravem intencionalmente o risco objeto do contrato. Porém, as normas dos arts 769 , $\$ \$ 1^{\circ} \mathrm{e} 2^{\circ}$, e do art. 770 , segunda parte, constituem um evidente retrocesso no que diz com a proteção que vem sendo, legal e jurisdicionalmente, conferida ao segurado, implicando verdadeiramente numa contradição com os deveres que decorrem da cláusula geral do art. 422. Por esta razão, entendo devam aqui prevalecer as regras do Código de Defesa do Consumidor, inclusive por força da proteção constitucional que é assegurada ao seguradoconsumidor e da regra de reenvio constante do art. 777, evitando-se assim, por força de interpreração intra e intersistemática, a injusta conseqüência resolutória, prevista nas ciradas regras.

${ }^{133}$ MOISSET DE ESPANES, Luis, La Teoria de los Propios Actos y la Doctrina y la Jurisprudencia Nacionales, apud BORDA, op. cit, p. 26.

\$34 Isto é, do pedido anulatório, ou resolutório, ou ainda do ato de retirada das tratativas negociais. 
O princípio da confiança também domina o Direito de Empresa, impondo aos administradores deveres de tutela e de consideração aos legítimos interesses dos sócios e da sociedade. É preciso considerat que o termo "empresa" significa, no Código recém aprovado, atividade econômica organizada no sentido da produção e da circulação da tiqueza, de modo que "toda vez que o negócio jurídico, disciplinado na parte do Direito das Obrigaçóes, adquire uma estrutura própria adequada à realização do fato econômico, surge a empresa":35. Assim, incidem à atividade empresarial os princípios que regem o Direito das Obrigações em sua integralidade.

Esses deveres de tutela e consideração manifestam-se de forma escalonada, consoante a natureza do vínculo, explicando Clóvis do Couto e Silva que nos negócios bilaterais - v.g, os contratos de intercâmbio - o interesse, conferido a cada participante da telação jurídica (mea res agitur) "encontra a sua fronteira nos interesses do outro figurante, dignos de serem protegidos" (de modo que) "o princípio da boa-fé opera, aqui, significativamente, como mandamento de consideraçấo $0^{136}$ ". Diversa e maior é a intensidade dos deveres decortentes da boa-fé quando os interesses em jogo não são contrapostos, como acontece nos contratos bilaterais, mas quando verifica-se uma atividade em proveito alheio: nos acordos de gestão, nos negócios fiduciários em getal "o dever de levar em conta o interesse da outra parte (tua res agitur) éo conteído do dever do gestorou do fiduciário".

Porém, é nas relações obrigacionais marcadas pela comunhão de escopo, como as relações de sociedade, que a cooperação se manifesta en sua plenitude (nostra res agitur). A qui "cuida-se de algo mais do que a mera consideração, pois existe dever de aplicação à tarefa supra-pessoal, e exige-se disposição ao trabalho conjunto e a sacrifícios relacionados como fim comum ${ }^{m i 37}$.

Observa-se, assin, que os deveres decorrentes da lealdade e da boa-fé, ordenados em gtaus de intensidade conforme a categoria dos atos jurídicos a que se ligam, encontram a sua máxima intensidade nas relações societátias que, tal como as relações de famillia, envolvem interesses suprapessoais.

\footnotetext{
${ }^{335}$ REALE, Miguel, O Proj̣eto de Código Civil - Situação atual e seus problemas fundamentais, cit., p.48.

\$36 COUTO e SILVA, CLÓVIS, A Obrigação como Processo, São Paulo, José Bushatsky, 1976, p. 30.

${ }^{1.37}$ COUTO E SILVA, cit., p. 31, grifamos.
} 
Por esta razão impõe o novo Código expressiva carga de responsabilidade aos administradores e sócios, seja determinando condura consoante o standard da pessoa "ativa e proba" (art. 1.011), seja impondo responsabilidade solidária perante a sociedade e aos terceiros prejudicados por culpa no desempenho de suas funções (art. 1.016), seja determinando a não-isenção de responsabilidade do sócio que se retirou, ou foi excluído, ou dos herdeiros de sócio falecido, pelas obrigações sociais, por certo tempo (art. 1.032).

Há de se convir, no entanto, que o Direito da Empresa constitui o setor, no novo Código, em que mais escassas são as cláusulas gerais. É certo que, como já observei, atingem este campo os princípios do Direito Obrigacional como um todo e ainda as normas da Parte Geral, tais quais as do art. 50 (desconsíderação da personalidade jurídica) e 187 (ilicitude, por abuso de direito e desvio de finalidade). Porém, considerando-se o estreito legalismo que ainda domina, como marca cultural, boa parte da doutrina e jurisprudência brasileiras, mais oportuno pareceria aqui repetir os preceitos ético-jurídicos tão amplamente postos anteriormente. A exigência de rigor técnico não deveria obstar, nesta matéria, a imposição de modelos que reenviam a idéias éticas e que podem proporcionar o controle, pelo Poder Judiciário, de domínio onde se travam relações econômicas essenciais à comunidade.

É ainda a exigência de eticidade, já aí como mandamento de eqüidade, que está no substrato da regra do art. 396, segundo a qual não havendo omissão imputável ao devedor não incorte este em mora; do art. 413 que atribui ao juiz o dever de reduzir "eqüitativamente" a cláusula penal se a obrigação principal tiver sido cumprida em parte, ou se o montante da penalidade for manifestamente excessivo, "tendo-se em vista a natureza e a finalidade do negócio"; e do acolhimento, no axt. 478, da doutrina da excessiva onerosidade, de clara inspiração em Emilio Betti: não é équo o locupletamento na relação contratual, que é relação de colaboração ${ }^{138}$.

A regra é completada pelo disposto no art. 479, possibilitando evitar a resolução se o réu modificar "eqüitativamente" as condições do contrato, e no art. 480, alusivo aos contratos unilaterais, assim entendidos aqueles em que a carga de onerosidade recai apenas sobre uma das partes.

Reflexo da eticidade é também o preceito do art. 317, atinente à excessiva desproporção entre prestação e contraptestação no momento do pagamento, que apanhará inúmeros casos

\footnotetext{
:38 O Projeto tem recebido expressivas críticas, neste ponto, por não ter acolhido a doutrina da base objetiva do negócio, formulada na Alemanha por K. LARENZ, a qual, como é sabido, exige apenas a excessiva desproporção entre prestação e contraprestação, não imputável aos contratantes, e causada por circunstâncias supervenientes que desequilibxem o contrato. Veja-se, neste sentido, AGUIAR JÚNIOR, Ruy Rosado, "O Projeto de Código Civil: Obrigaçóes e Contratos", Revista do Conselho da Justiça federal, cit.
} 
de entiquecimento injustificado, aliás previsto nos artigos 884 a 886 . Bem assim é a eqüidade que informa a regra do parágrafo único do art. 738 , possibilitando ao juiz reduzir "eqüitativamente" a indenização devida por prejuízo sofrido em razão de contrato de transporte, quando a vítima houver concorrido para a ocorrência do dano. A mesma diretriz fundamenta a norma, já aludida, referente à desconsideração da personalidade jurídica (art. 50): não é équo que alguém se utilize de um instituto jurídico (a personificação jurídica), para fugir de suas responsabilidades.

É também por exigência ética que o casamento é fundado no princípio da "comunhão plena de vida" (art. 1.511). Não seria admissível que um projeto existencial da dimensão do estabelecido pela união conjugal não fosse eticamente pautado pela comunhão de vida, pelo compartilhamento de sucessos e de infortúnios, de esperanças e de realizações e também de mútuos deveres fundados no afeto, no vínculo existencial que une os partícipes da família. A cláusula geral da comunhão plena de vida foi proposta, no Anteprojeto, por Clóvis do Couto e Silva, que assim explica a sua operatividade:

"A expressão comunhão de vida constitui-se em "cláusula geral", conceito operativo e representa para o direito de familia o mesmo que a boa-fé para o direito em geral e, em particular, para o das obrigações. Os princípios que dele (SIC) podem derivar não são determináveis "a priori". (...) Conceito de conteúdo não inteiramente determinado, será objeto de concreção através da atividade jurisdicional, sendo elemento relevante para o raciocínio casuístico, para a solução dos problemas concretos de direito de família. Sua função principalé a de sintetizar e enriquecer os deveres mútuos dos cônjuges, que de modo algum se esgotam na enumeração do Código Civil"'39.

Bem assim esta norma, com caráter nitidamente prospectivo, tem a virtualidade de gerar, no futuro, "ao compasso das transformações por que passa a família, novos meios projetivos da comunidade jurídica que surge com o casamento ${ }^{140}$. Novos problemas, e novas valorações acerca da comunidade familiar podem, pois, ser continuamente apanhados pela regra, cuja densificação está, também, ao encargo da jurisprudência.

\footnotetext{
13. COUTO e SILvA Clóvis, Princípios para a Reforma do Direito de Família, cit., p. 159

140) Ydem, ibidem.
} 
Por outro lado, tenho que a comunhão plena de vida é dominada pelo que Celso Lafer ${ }^{34}$, com base nas liçōes de Hannah Arendt denominou de princípio da exclusividade; para a tutela da dignidade humana exige-se, além da luz da esfera pública, "a proteção das sombras que permitem a transparência dos sentimentos da vida intima" ${ }^{\text {"42 }}$, a exclusividade regendo aquela especial esfera da vida privada em relação à qual é defesa a interferência alheia, pois é o locus, material e espiritual, no qual "escolbemos aqueles com os quais desejamos passar nossas vidas, amigos pessoais e aqueles que amamos", não sendo nossa escolha "guiada, de fato, por nenhum padrão objetivo ou normas, mas, inexplicável e infalivelmente, afetada pelo impacto de uma pessoa em sua singularidade, sua diferença em relacão a todas pessoas que conbecemos"143.

Limite à interferência da esfera pública (no duplo sentido de Poder Público e opinião pública), o princípio da exclusividade mantém na decisão da família a sua intimidade, o seu "modo de ser" particular. É do casal, por exemplo, a decisão quanto ao planejamento familiar (art. $1.565, \$ 2^{\circ}$ ) determinando explicitamente o novo Código ser defeso a qualquer pessoa, de direito público ou privado, "interferir na comunhão de vida instituída pela família" (art. 1.513), o que, evidentemente, não impede a tutela estatal aos filhos quando necessário (arts. 1.584 a 1.589 e art. 1567, \ único), pois o princípio da exclusividade incide em tudo o quanto não envolva direitos de terceiros ${ }^{1 / 4}$. Em relação aos filhos, os pais, que estão em relação de igualdade (art. 1.511) exercem dever-poder denominado "poder familiar""145 devendo dirigir a sociedade conjugal "em colaboração" $\mathrm{e}$ "sempre no interesse do casale dos filhos"(art. 1.567).

A igualdade entre homem e mulher, no casamento, também decorrente de uma nova ética nas relações entre os sexos, reflete-se na modificação no regime de bens - o regime da comunhão parcial, com conunhão de aqüestos (art. 1.640) será o regime notmal, extensível aos companheiros, salvo convenção en contrátio (art. 1725) - e, no Direito Sucessório na mudança da regra pela qual o cônjuge supérstite não concorria com descendentes e ascendentes. $\mathrm{O}$ art. 1.845 dispõe: "São berdeiros necessários os descendentes, os ascendentes $e$ o cônjuge". São herdeiros necessários, portanto, os que se ligam ao falecido por relações de

141 LAFER, Celso, A reconstrução dos Direitos Humanos: um diálogo com o pensamento de Hannah Arendt. São Paulo, Companhia das Letras, $19911^{2}$ reimpressão, pp. 267 e 268.

162 LAFER, Celso, A reconstrução dos Direitos Humanos, cit., p. 267.

14.7 ARENDT, Hannah, apud LAFER, op. cit., pp. 267 e 268.

144 LAFER, op. cit., p. 268.

145 Expressăo utilizada em substituição ao antigo "pátrio poder" no Capitulo V, do Livro IV, axts. 1.630 a 1.638 . 
afeto, mantida, é certo, a regra da relativa liberdade de testar ${ }^{146}$.

Regra por todos os motivos criticável, porém, é a do inciso II do art. 1.641, que impõe aos maiores de 60 anos o regime da separação de bens no casamento. Como já demonstrou em paradigmática decisão o Tribunal de Justiça de São Paulo ${ }^{147}$, é claramente atentatória à dignidade da pessoa considerar que o fato da idade - hoje em dia, não provecta - de 60 anos, retira da pessoa o poder de autodeterminação, impedindo-lhe o exercício da autonomia privada em tema tão essencialmente ligado ao princípio da exclusividade quanto é o da organização dos interesses econômicos do casal.

Relacionam-se ainda com o principio da eticidade as regras relativas ao "estado de perigo" (art. 156) e à lesão (art. 157), já referidas, e o princípio fixado no art. 944, que, como se viu, acolhe expressamente o dever de razoabilidade.

É justamente o dever de razoabilidade, exigência ética fundamental, que inspira o art. 571 , relativo à hipótese de, em contrato de locação por tempo determinado, o locatário devolver o imóvel antes do termo, quando deverá pagar multa. Neste caso, determina o arr. 572, "se a obrigação de pagar o aluguel, pelo tempo que faltar, constituir indenizaçâo excessiza, seráf facultado ao juiz em bases razaáreis".

Observa-se, pois, que no novo Código Civil brasileiro a equidade tradicionalmente associada ao Direito Natural torna-se, de modo incontroverso, direito positivo, devendo a jurisprudência - fonte formal de produção jurídica - ainda ampliar o seu conteúdo pela concreção dos variados modelos abertos contidos em seu texto.

Certas regras são de difícil classificação entre a eticidade e a socialidade. Assim, em tema de direitos reais, as vedações aos atos emulativos, desviados de sua função, no direito de propriedade, parecem ligar-se tanto a um dever getal de correção, decorrente da boa-fé, quanto ao princípio da função social. É o que agora examinarei.

\footnotetext{
146 No Direito brasileiro assegura-se aos herdeiros necessários a metade dos bens da herança, que constituem a legítima, regra posta no novoCódigo no art. 1.789 .

${ }^{147}$ TJSP, ap. civ. 007.512-4/2-00, 2. Câmara, j. 18.08.98, Rel. Des. César Peluso. Vide o substancioso comentário de RIBEIRO LOPES, Maurício, in Revista dos Tribunais 758/106-117.
} 


\section{B) A SOCIALIDADE COMO CARACTERÍSTICA DO DIREITO CIVIL CONTEMPORÂNEO}

Se a eticidade está no fundamento das regras civis, dúvidas não há de que o Direito Civil em nossos dias é também marcado pela socialidade, pela situação de suas regras no plano da vida comunitária. A relação entre a dimensão individual e a comunitária do ser humano constitui tema de debate que tem atravessado os séculos, desde, pelo menos, Aristóteles, constituindo, mais propriamente, um problema de filosofia política ${ }^{148}$, por isto devendo ser apanhado pelo Direito posto conforme os valores de nossa - a atual experiência jurídica.

O quadro que hoje se apresenta ao Direito Civil é o da reação ao excessivo individualismo característico da Eta codificatória oitocentista que tantos e tão fundos reflexos ainda nos lega. Se às Constituições cabe proclamar o princípio da função social -o que vem sendo regra desde Weimar ${ }^{149}$ - é ao Direito Civil que incumbe transformá-lo em concreto instrumento de ação ${ }^{150}$. Mediante o recurso à função social e também à boa-fé - que tem uma face marcadamente ética e outra solidarista - instrumentaliza o Código agora aprovado a diretriz constitucional da solidariedade social, posta como um dos "objetivos fundamentais da República" ${ }^{\text {151. }}$.

Essa instrumentalização ocorre em três específicos domínios, o do contrato, o da propriedade e o da posse.

\section{b.1) a função social da propriedade e da posse.}

Comecemos pela disciplina da propriedade, "il terribile diritto" de que tratou Rodotà ${ }^{152}$ e que está, no novo Código, claramente informada pela função social. Aqui - e também na posse - o princípio da função social, para além de relativizar ou temperar o

\footnotetext{
${ }^{1 * 8}$ Entre a vasta bibliografia veja-se CALERA, Nicolas López, Hay derechos colectivos? Individualidad y socialidad em la teoria de los Derechos, Barcelona, Ariel Derecho, 2000.

í9 $\mathrm{Na}$ Constituiçẫo brasileira o princípio da função social vem expresso nos arts. $5^{\circ}$, inciso XXIII, e 170. Acerca do tema escrevi em Mercado e solidariedade social entre cosmos e taxis: a boa-fé nas relações de consumo, ensaio integrante do livro A Reconstrução do Direito Privado - reflexos dos princípios e garantias fundamentais no Direito Privado, MARTINS COSTA, Judith (org), no prelo.

${ }^{150}$ Neste sentido REALE, Miguel, O Projeto de Código Civil - Situação atual e seus problemas fundamentais cit., p. 9.

:51 Constituição Federal, art. $3^{\circ}$, inciso III.

${ }^{152}$ RODOTÁ, Stéano, II terribile diritto, Bologna, Il Mulino, 1981, que li na tradução espanhola, El terrible derecho- Estudios sobre la propiedad privada, Madri, Civitas, 1986.
} 
individualismo que marcou o tratamento do direito da propriedade na codificação oitocentista, " $n \tilde{a} o$ está, de forma alguma, confinado a mero apêndice do direito de propriedade, a simples elemento configurador de seu conteúdo ${ }^{153}$ ", sendo muito mais que isso: "Por função social da propriedade", afirma Teori Zavascki,

"bá de se entender o princípio que diz respeito à utilização dos bens, e não à sua titularidade juridica, a significar que sua força normativa ocorre independentemente da específica consideração de quem detenha o título jurídico de proprietário. $O_{s}$ bens, no seu sentido mais amplo, as propriedades, genericamente consideradas, éque estão submet:das a uma destinação social, e não o direito de propriedade em si mesmo ${ }^{154}$.

A atribuição de uma função social à propriedade está inserida no movimento da funcionalização dos direitos subjetivos que, desde o final do século XIX vem promovendo a reconstrução de institutos centrais do Direito moderno, tais quais a propriedade e o contrato, como uma tentativa de "buscar um novo equilibrio entre os interesses dos particulares e as necessidades da coletividade" ${ }^{15 s}$. Com efeito, a cláusula da "função social" exerce papel central na superação do modelo proprietário oferecido no século XIX pelo Code Napóleon e pela Pandectística, possibilitando, nas palavras de Stefano Rodotà, as bases para a "reconstrução do instituto da propriedade" ".56.

Sendo a determinação do conceito de função social —_ sua autonomia científica condição necessária para que não se o reduza ao plano das motivações morais, políticas e ideológicas ${ }^{157}$, cabe mencionar, ainda que de passagem, as suas raízes e a significação que tem recebido da doutrina.

Como é por todos sabido, a noção de função social da propriedade começa a sua história com base nas formulações acerca da figura do abuso de direito, pela qual foi a

\footnotetext{
${ }^{153}$ Assim "ZAVASCKI, "Teori, "A tutela da posse na Constituifão e no Projeto do novo Código Civil", in A Reconstrução do Direito Privado - reflexos dos princípios e garantias fundamentais no Direito Privado, MARTINS-COSTA, Judith (org), no ptelo, gxifei.

${ }^{154} \mathrm{Idem}$. Isto porque, prossegue o autor, "bens, propriedades, são fenômenos da realidade. Direito-e, portanto, direito da propriedade -éfenômeno do mundo dos pensamentos. Utilizar bens, ou náo utilizálos, dar-lhes ou não uma destinação que atenda aos interesses sociais, representa atuar no plano real, e não no campo puramente juridico

${ }^{155}$ Neste sentido, Francesco GALGANO,Il Diritto Privato fra Codice e Costituzione, Bolonha, Zanichelli, $2^{a}$ edição, 1983, p. 152.

${ }^{156}$ RODOTA, S. Proprietà (diritro vigente), in Novissimo Digesto Italiano, vol.XYV, 1967, p.134.

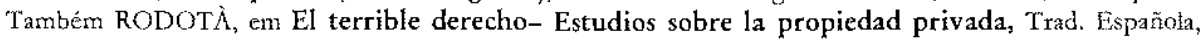
Madri, Civitas, 1986, p. 81.

${ }^{157}$ RODOTÀ, S. El terrible derecho - Estudios sobre la propiedad privada,cit. p. 212.
} 
jurisprudência francesa gradativamente impondo certos limites ao poder absoluto do proprietário ${ }^{158}$. A abordagem, contudo, ainda ocorria no plano dos "limites", fatores externos à estrutura mesma do direito subjetivo, que restava inatingido, tendo-se a propriedade como um "droit absolu et sacré", excepcionalmente restringido nas hipóteses de abuso.

Este entendimento inicial sofreu forte ruptura nos finais do século XIX pela pena de Leon Duguit ${ }^{159}$ que promoveu uma crítica radical à noção mesma de direito subjetivo, propondo substituí-lo pela "noção realista de função social", daí assentando, em célebre dito, que a propriedade é uma função social ${ }^{161}$ (pois esta lhe é inerente), e não tem, meramente, uma função social. É bem verdade que a idéia da "propriétéfonction" já havia sido anteriormente expressa por Proudhon ${ }^{164}$, mas é Duguit quem aprofunda, em termos jurídicos, a polêmica, centrando sua atenção no rechaço à idéia de um sistema de direito privado orientado pelo conceito de direito subjetivo, enquanto poder reconhecido a uma pessoa de impor a sua vontade às demais.

Seguindo essa orientação, afirma, ainda no início do século XX, Geonges Ripert

"(...) os direitos não são outorgados ao homem senão para lhe permitir que preencha sua função na sociedade, não bá qualquer razão para lhe conceder direitos que the permitiriam subtrair, da utilizaf̧ão comum, bens úteis a todos." 162

O intenso debate douttinário que seguiu-se a estas asserções acabou por refletit-se nas legislações do início do século XX, da qual é expoente a Constituição de Weimar a qual, no célebre artigo 153 estabeleceu:" A Constituição garante a propriedade. O seu conteúdo e os seus limites resultam de lei. (...) A propriedade obriga e o seu uso e exercício devem ao mesmo tempo representar uma função no interesse social. ${ }^{\prime 163}$

\footnotetext{
${ }^{158}$ Assim sentença do Tribunal de Colmar, de maio de 1885 , que se tornou célebre por impor como limite ao direito de propriedade o seu exercício em prol de um interesse séxio e legítimo - um marco na construçăo da doutrina do abuso de direito (DUGUTT, Léon, La responsabilidad del propietario y la jurisprudencia francesa, apend. in: Las transformaciones del Derecho (público y privado), trad. De Carlos POSADA, Buenos Aires, Editorial Heliasta, 1975, pp. 259 e ss.) ${ }^{159}$ DUGUrT, L., El derecho subjetivo y la función social, in Las transformaciones del Derecho (público y privado), cit., p.178.

${ }_{360}^{60}$ DUGYT, L. La propiedad función social in Las transformaciones del Derecho (público y privado), cit., p.241; e El derecho subjetivo y la función social", na mesma obra, p.179.

"GrPROUDHON. Qu'est-ce que la propriété, in Oeuvres Choisies. Paris, Gallinatd, 1967, p. 111. ${ }^{t a}$ Apud PACHECO BARROS, Wellington, A propriedade agrária e seu novo conceito jurídico constitucional, Porto Alegre, Revista Ajuris, $\mathrm{n}^{\circ} 32$.

${ }^{163}$ In Textos Históricos do Direito Constitucional, oxg. e tradução de Jorge MuRANDA, Lisboa, Imprensa Nacional - Casa da Moeda, 1980.
} 
Desde então, e progressivamente, as Constituições da segunda metade do Século XX passaram a aderir à fórmula, pela qual admite-se que os poderes do titular de um direito subjetivo estão condicionados pela respectiva função, indicando a funcionalização justamente a atribuição de um poder tendo em vista certa finalidade ou a atribuição de um poder que se desdobra como dever, posto concedido para a satisfação de interesses não meramente próprios ou individuais, podendo atingir também a esfera dos interesses alheios.

Isto não significa dizer que o direito de propriedade tenha deixado o campo da regulação privada, passando a integtar o domínio do Direito Público ${ }^{164}$. É que a atribuição de função social aos bens enseja, em nossa mente antropocêntrica, centrada e concentrada na idéia de "direito subjetivo", um verdadeiro giro epistemológico, para que passemos a considerar o tema a partir do bem, da res, e de suas efetivas utilidades: em outras palavras, a função social exige a compreensão da propriedade privada já não como o verdadeiro monóliro passível de dedução nos códigos oitocentistas, mas como uma pluralidade complexa de situações jurídicas reais, que englobam, concomitantemente, um complexo de situações juridicas subjetivas ${ }^{165}$, sobre as quais incidem, escalonadamente, graus de publicismo e de privatismo, consoante o bem objeto da concreta situação jurídica.

A perspectiva de um escalonamento em graus de publicismo e privatismo a incidir nos institutos componentes do Dixeito Privado foi traçada em meados do século XX por Ludwig Raiser que, atento ao complexo e plurifacetado painel da vida social contemporânea que esfacelava o rígido muro divisório erigido entre o Direito Público e o Privado desde a Codificação, propôs visualizar o ordenamento como uma elipse estruturada em dois núcleos

\footnotetext{
${ }^{164}$ Assim, em posição em nosso ver equivocada, o mestre Celso Antônio BANDEIRA DE MELLO. É o que afirna em artigo inúmeras vezes citado na bibliografsa brasileira sobre o tema:"O direito de propriedade - ou seja, o reconbecimento de que a organização jurídica da Sociedade (Estado) dispensa aos poderes de alguém sobre coisas - encarta-se, ao nosso ver, no Direito Público e não no Direito Privado. É evidente que tal Direito comporta nelações tanto de Direito Público quanto de Direito Privado. Entretanto, o direito de propriedade, como aliás sempre sustentou o prof. Orualdo Aranba Bandeira de Melloé,essencialmente, um direito confrgurado no Direito Público e- desde logo-no Direito Constitucional" (Novos aspectos da função social da propriedade no direito público, São Pattlo, Revista de Direito Público, vol. 84, out-dez. 1987,p.39. Diferentemente, averba GRAU,é pressuposto fundamental da função social a propriedade privada". (GRAU, Eros Roberto, A Ordem Econômica na Constituição de 1988, São Paulo, Malheiros, $5^{\text {* }}$ edição, 2000, p. 253).

${ }^{165} \mathrm{~A}$ função social da propriedade designa um complexo de obrigações, de encargos, de limitaçôes, de estímulos e de ameaças que formam parte da regulamentação do direito de propriedade. A função social da propriedade não se ajusta a um só recurso de técnica jurídica: é todo um complexo de recursos mediante os quais, de forma direta ou indireta o proprietário é levado ao campo da função social. (Neste sentido, A. BALLARIN MARCIAL, Evolução do princípio jurídico do direito de propriedade rural, Revista de Direito Agrário, n.12, ano 10, 1994, p.28).
} 
ou pólos, um centrado na autonomia privada, na autodeterminação e na idéia de responsabilidade social, outro no interesse público e na heterodeterminação, os quais constituiriam, respectivamente, pólos de irradiação de graus de privatismo e de publicismo ${ }^{166}$. O Direito Privado teria, assim, uma estrututa escalonada, consoante o grau de relevância pública ${ }^{167}$ de cada situação social concretamente regulada. Em outras palavras, um mesmo instituto - por exemplo, a propriedade, ou o contrato - seria chamado a desempenhar diferentes funções, ora sendo marcado por um grau elevado de publicismo (o que conduziria, no caso da propriedade, por exemplo, à desapropriação), ora por graus de privatismo, sendo então ensejado ao seu titular um maior poder de disposição.

Embora adotando diversa perspectiva, entre nós também reconhece Eros Roberto Grau que "a propriedade não constitui uma instituição única, mas o conjunto de várias instituições, "relacionadas a diversos tipos de bens" "168 , o que, de resto, não constitui uma novidade em termos históricos, bem tendo demonstrado Paolo Grossi que a propriedade, no Medievo, era medida pelo critério do reicentrismo, e não do antropocentrismo ${ }^{169}$, o que levava à sua concepção plural. Sem tecair emn anti-histótico anacronismo, pode-se dizer que hoje em dia perspectiva-se, na base da própria idéia de um "direito de propriedade", um complexo de situações, deveres, obrigações, ônus jurídicos, a par de direitos subjetivos e poderes formativos, que se põem em perspectiva escalonada. Neste sentido inclina-se Perlingiere, segundo o qual, "em realidade, a propriedade privada não se configura como direito subjetivo, individualistamente compreendido, mas como situação unitária e complexa composta por poderes, mas também por obrigą̧oes, deveres, ônus, a qual, diferentemente da propriedade pública, não é função, mas tem função social ${ }^{\text {'170 }}$.

Isso porque "a propriedade não tem uma estrutura natural e originária" antes decorrendo os seus efetivos contornos "segundo a normativa vigente, a evolução das

${ }^{166}$ RAISER, Ludwig, "Il futuro del Diritto Privato", in: Il Compito del Diritto Privato, trad. Ytaliana de Marta Graziadei, Milão, Giuffrè, 1990.

t67 RAISER, ob. cit., p. 232.

${ }^{16}{ }^{6} \mathrm{GRAU}$, Eros Roberto, A Ordem Econômica na Constituição de 1988, cit., p. 257.

${ }^{16 " P a r a ~ o ~ e x a m e ~ d a s ~ " p r o p r i e d a d e s " ~ n o ~ D i r e i t o ~ M e d i e v a l ~ v e j a-s e ~ G R O S S I, ~ P a o l o, ~ P r o p r i e t a ̀ ~-~ d i r i t t o ~}$ intermedio, verbete in: Enciclopedia del Diritto, vol. XXXVII, 1988 e L'Ordine Giuridico Medievale, Laterza, Roma-Bari, 1995, p.72 e ss.

270PERLINGIfRE, Płetro, Il Diritto Civile nella Legalità Costituzionale, Nápoles, ESI, $2^{a}$ ediçâo, 1991, p. 452, traduzi. No original: "In realtà la proprietà privata non si configura come diritto soggetivo, individualisticamente inteso, ma come situazione unitaria e compless composta da poterima anche da obblighi, doven, oner, la quale, a differenza della proprietà pubblica, non è funzione, ma bá funzione sciale".

${ }^{17}$ Idem, ibidem. 
relações patrimoniais, em sentido lato, e o papel que estas bistoricamente adquiriram no mais amplo sistema das relações sociais e políticas" ${ }^{\prime 72}$, de sorte que, conquanto atinente imediatamente aos bens, objeto do direito, a função social, "uma vez configurar conotação essencial ao estatuto proprietário, não pode não contribuir para desenbar a estrutura da relativa situação subjetiva" ${ }^{\text {"t73. }}$.

Em outras palavras, o atributo da função social não é meramente "externo" ao direito: constituindo, em caráter imediato, função social do bem (objeto do direito), reflete-se no conjunto de situações jurídicas incidentes sobre o bem, e assim, de forma mediata, ela, a função social, acaba por integrar o complexo de direitos e deveres subsumidos no conceito de "direito de propriedade", modificando-se a idéia construída pelo Jusracionalismo que o perspectivara como "poder da vontade", como direito natural do homem sobre as coisas, em cujo conteúdo não cabem deveres e limitações. É o que, também afirma Eros Roberto Grau, segundo o qual o princípio "passa a integrar o conceito jurídico-positivo de propriedade, (...) de modo a determinar profundas alteraçôes estruturais na sua interioridade ${ }^{p 174}$.

A concepção complexa e escalonada da função social da propriedade teve o mérito de superar os entendimentos dualistas, pelo qual a função social estaria atada à "natureza" de certos tipos de propriedade (por exemplo, a propriedade dos bens de produção). Não sendo mais considerado monoliticamente o direito, nem apenas visualizado externamente, a questão é de saber como se estrutura, em diferentes graus, a função social, conforme a função que o direito é cbamado a operar e às efetivas utilidades da res para a sociedade, sendo certo que nem a Constituição brasileira nem o novo Código Civil traduzem a distinção, determinando apenas que 'a propriedade (1sto é, qualquer propriedade) atenderá à sua função social'.

\footnotetext{
"Idem, ibidem, traduzi, no original: "secondo la normativa vigente, l"evoluzione dei rapporti in senso lato patrimoniali ed il nuolo che questi hanno storicamente acquisto nel piu ampio sistema dei rapporti sociali e politici".

${ }^{7 / 3}$ Idem, ibidem, traduzi.No original: "la funzione sociale, una volta configurata connotazione essenziale allo statuto proprietario, non può non contribucre a disegnare la struttura della relativa situazione soggetiva".

${ }^{174} \mathrm{GRAU}$, Eros Roberto, A Ordem Econômica..., . cit., p. 260.
} 
E se toda e qualquer propriedade "atenderá à sua função social", assim não apenas a propriedade do solo ou a dos bens de produção, mas também a propriedade imaterial e a propriedade da empresa, por exemplo. Como conseqüência,

'O uso do direito é correto se, para além de respeitar as proibiçôes e os limites expressamente predispostos pelo legislador, se substancia em um comportamento conforme à função social, que pode consistir seja em omissões seja em adimplemento de deveres positivos, atuativos dos interesses individuais e gerais ${ }^{375}$.

Iss está a indicar que a função social tem funções negativas e positivas, não constituindo apenas na imposição de limites, mas, por igual, conduzindo ao nascimento de deveres jurídicos positivos. Com efeito, equívoco devido a uma literatura hoje já ulttapassada, vigorante nos primeiros decênios do século XX, percebia-se a cláusula da função social tão somente em sua dimensão negativa, como proibição do exercício de determinados comportamentos. No Estado Social contemporâneo, todavia, que procura "a harmonia entre, num lado, idéias liberais de uma economia livre $e$, no outro, a igualdade de chances e a distribuição de riquezas ${ }^{3176}$, a função social predeterminada à propriedade privada não concerne exclusivamente à questão dos seus limites, assumindo, ao contrário, "um papel de tipo promocional, no sentido que a disciplina das formas proprietárias e a sua interpretação devem ser "atuadas"para garantir e para promover os valores nos quais se funda o ordenamento" $"$.

\footnotetext{
"s: PERIINGIERE, op. cit., p. 449, traduzi. No original: 'L'uso del diritto è corretto se, oltre a realizzare il nispetto dei divietie dei limiti $\Subset$ pressamenteprodisposti dal legidatore, sisustanzia in un compontamento conforme all a funzione sociale, che può consistere sai in omissioni sai in adempimenti diobblighipositivi attuativi di interessi individualie generali" 1"Assim KRELL, Andreas, referindo-se à Alemanha, mas em citação que em tudo se aplica ao modelo nomativo da ordem econômica desenhado na Constituiçào Brasileira (in Controle Judicial dos Serviços Públicos Básicos na Base dos Direitos Fundamentais Sociais, texto integrante de A Constituição Concretizada, org., SARLET, Ingo Wolfgang, Porto Alegre, Livraria do Advogado, 2000 , p. 37.

177PERLINGIERE, P., op. cit., p. 445, traduzi, no original: "un rwolo di tipo promozionale, nel senso che la disciplina delle forme proprietaric ele lono interpretazione dovranno essere attuate per garantive eper promuotere ivalon sui quali se fondal"ordinamento".
} 
Assim ocorre entre nós por força do art. 170, incisos II e III que encerram ptincípios constitucionais impositivos, uma vez cumprirem a dupla função de instrumental e de objetivo específico a ser alcançado, justificando não só a reivindicação de políticas públicas comprometidas com a sua concretização ${ }^{178}$ quanto interpretação produtiva, que não lhe restrinja a eficácia.

Reconhecendo esta perspectiva, deixando antever que a idéia de propriedade é uma idéia plural, e, regendo-as mediante a cláusula geral do $\$ 1^{\circ}$ do art. 1.228 , que põe em relevância justamente a utilidade dos bens - isto é, as frnahdade econômicas e sociais dos bens objeto do direito de propriedade -, o novo Texto Civil trata escalonadamente do exercício deste direito, conforme a intensidade dos graus de publicismo e de privatismo incidentes em cada situação concreta.

A leitura complessiva dos dispositivos da Parte Geral, notadamente a cláusula geral da ilicitude do art. 187, e a introdução do conceito de pertença, no art. 93, bem como das tegras da Parte Especial levam, inelutavelmente a esta conclusão, sendo de exponencial importância a compreensão do tratamento da do à posse, em si mesma considerada e em sua relação com a propriedade, e a leitura do art. 1228 e de seus parágrafos.

No art. 1.228 determina-se que "o proprietário tem a faculdade de usar, gozar e dispor da coisa, e o direito de reavê-la do poder de quem quer que injustamente a possua ou detenba", preceituando o seu $₫ 1^{\circ}$ que "o direito de propriedade deve ser exercido em consonância com as suas finalidades econômicas e sociais, e de modo que sejam preservados, de conformidade com o estabelecido em lei especial, a flora, a fauna, as belezas naturais, $o$ equilibrio ecológico e o patrimônio bistórico e artístico, bem como evitada a poluição do ar edaságuas".

Completam esta regra a dicção do $\$ 2^{\circ}$, pela qual próbe-se ao proprietário "os atos que não trazem ao proprietário qualquer comodidade, ou utilidade, e sejam animados pela intenção de prejudicar outrem" e do art. 1.277 , relativa aos direitos de vizinhança, que sanciona o "uso anormal" da propriedade, sendo essencial à compreensão do conjunto normativo da propriedade também as normas que instituem o direiro de superfície (arts. 1.369 a 1.377 ), as que regulam o condomínio (arts. 1.331 a 1.358) e o exercício das servidões (arts. 1.378 a 1.389) e da usucapiäo (arts.1238 e ss.).

Por outro lado, por decorrerem do princípio da função social funções positivas e negativas, o novo Código impõe o dever de usar o direito de propriedade em conformidade com as finalidades econômicas e sociais, na qual se incluem os fatores ecológicos e ambientais e os relativos à preservação do patrimônio histórico e artístico, de inegável interesse coletivo, transindividual. Há, pois, na norma, um claro direcionamento promocional.

${ }^{177}$ Eros Grau, in A Ordem Econômica na Constituição de 1988. São Paulo, ed. RT, 1991, $2^{2}$ ed., p. 244. 
Já do ponto de vista das funções negativas, o proprietário não pode exercer "anormalmente" o seu direito, assim entendido, a meu juizo, o exercício abusivo ou desviado das finalidades arroladas no citado $\Omega^{\circ}$ - não podendo, por igual, furtar-se ao alargamento da servidão quando as necessidades "da cultura ou da indústria, do prédio dominante" assim determinarem, ainda que mediante indenização (art. 1.385, $\$ 3^{\circ}$ ).

Contudo, não se esgota aí a operatividade do princípio, o qual projeta a sua incidência por todo o corpus codificado e ainda para alén, mesmo para as leis especiais que têm a propriedade como objeto de regulação.

É porque o $\$ 1^{\circ}$ do art. 1.228 constitui cláusula geral na matéria, regendo não apenas o exercício do direito de propriedade regulado pelo Código quanto as demais formas, as "propriedades"1779 justifica-se, pela extrema relevância pública que pode revestir determinados bens, a regra do parágrafo $4^{\circ}$ do art. 1.228 que institui uma peculiar forma de desapropriação por ato judicial, fundada na utilidade social da posse e na destinação do bem expropriado.

Essa regra é digna de nota por variados motivos, entre eles a sua oportunidade num país como o Brasil, onde o problema fundiário permanece intocado e irresoluto através dos séculos. Aí se revela, para além da função social da propriedade, a função social da posse que, no Código agora aptovado, não se prende apenas à concepção abstrata de Von Jhering, refletida no art. 485 do vigente Código, mas engloba, também, a noção autônoma da posse ${ }^{189}$. Por isso, paralelamente ao regramento da posse como mera ocupação do bem, o conceito de "posse-trabalbo", aquela posse que "vem acompanbada de um ato criador do trabalho bumano" ${ }^{\text {".81 }}$ e que, bein por isso, deve ter uma proteção maior do que a ourra.

Preceitua o parágrafo $4^{\circ}$ do art. 1.228: "O proprietário também pode ser privado da coisa se o imóvel reivindicado consistir em extensa área, na posse ininterrupta e de boa-fé, por mais de cinco anos, de considerável número de pessoas e estas nela bouverem realizado,

${ }^{179}$ Acerca das "propiedades", em análise histórica, ceja-se de Paolo GROSSI, além das obras já citadas, La propiedad y las propiedades, un analisis histórico, trad. LÓPEZ Y LÓPEZ, Angel, Madrid, Civitas, 1992. No preâmbulo desta obra, observa com a agudeza habitual López y lópez, dissolvido o mito oitocentista do conceito unitário de propriedade, atualmente não se deve mais falar em propriedade. Pelo contrário, fale-se "nas propriedades", o que significa, "cambiar absolutamente de ángulo visual, significa contemplar el fenómeno de la apropiación prizada desdel a perspectiva de la relevancia económicosocialde los bienes, no desde aquella outra que pivota sobre la abstracta consideración de étos, y en consecuencia se resuel veen la simplicidad, unidad y bomogeneidad del poder atribuido a un sujeto, siempre identico a si mismo y, por ende tambiém abstracto (LÓPEZ Y LÓPEZ, Angel, "Prólogo para Civilistas", in GROSSI, Paolo, La propiedad y las propiedades, un analisis histórico, cit.,p. 11).

"Bo Acerca do tema escreveu VARELA, Laura Beck, "A Tutela da Posse entre abstração e autonomia: uma abordagem bistórica," in A Reconstrução do Direito Privado - reflexos dos princípios e garantias fundamenrais no Direito Privado, MARTINS COSTA, Judith (org)., no prelo.

${ }^{181}$ Assim REALE, Miguel, O Projeto de Código Civil - Situação atual e seus problemas fundamentais, cit, p. 54 . 
em conjunto ou separadamente, obras e serviços considerados pelo juiz de interesse sociale econômico relevante". Completa a norma o $\$ 5^{\circ}$, pelo qual "no caso do parágrafo antecedente, o juiz fixará a justa indenização devida ao proprietário; pago o preço, valerá a sentença como título para a transcrição do imóvel em nome dos possuidores".

Esta regxa recebeu inúmeros ataques, havendo quem contestasse a sua constitucionalidade, por atentatória ao direito de propriedade ${ }^{182}$. Nos subsídios ofertados quando do exame das Emendas, Luiz Edson Fachin acertadamente opinou que "o mecanismo, disposto no parágrafo que deve ser mantido, é de uma inovação elogiável, coerente com o sentido de função social da propriedade" ${ }^{\text {"83 }}$, assim logxando-se afastar a emenda supressora. Segundo Reale ${ }^{i 84}$, trata-se de "inovação do mais al to alcance, inspirada no sentido social do direito de propriedade, implicando não só novo conceito desta, mas também novo conceito de posse, que se poderia qualificar como sendo posse-trabalho (...). Defende o Coordenador da Comissão Codificadota a idéia de que a lei deve outorgar especial proteção à posse "que se traduz em trabalho criador, quer este se corporifique na construção de uma residência, quer se concretize em investimentos de caráter produtivo ou cultural", o que justificaria o discrimine, na própria tegulação normativa, entre a "posse simples", aquela que é "simples poder manifestado sobre uma coisa 'como se' fora atividade do proprietário" e aquela que chama de "posse qualificada" pois "enriquecida pelos valores do trabalbo". A "posse trabalho", está na base da peculiar forma expropriatória contida nos mencionados $\$ 4^{\circ} \mathrm{e} 5^{\circ}$. Aliás, como salienta Zavascki, o instituto desafiará, dogmaticamente, a argúcia da doutrina e, sobretudo, dos juizes, pois "fundado em diversos conceitos abertos ("extensa área", "considerável número de pessoas", "obras e serviços de interesse econômico e social relevante", "justa indenização", haverá de ter sua finalidade social bem compreendida para que possa ser adaptado às variantes circunstanciais do cada caso concreto" 85 .

\footnotetext{
${ }^{182}$ Assin a Emenda 135, do Senador Gabriel HERMES, rejeitada.

183 "Primeiros subsídios para exame das emendas apresentadas perante a Comissão Especial ao Projeto de Leida Càmara $n^{\circ} 118$, de 1984, que institui o Código Civil-Livro III, Direito das Coisas", in O Projeto de Código Civil no Senado - Tomo II, cit., p. 311.

${ }^{184}$ REALE, Miguel, O Projeto do Novo Código Civil, cit,, p. 82.

${ }^{725}$ ZAVASCKI, Teori, "A tutela da posse na Constituição e no Projeto do novo Código Civil", cit. Entende porém o autor que não se erata de una forma de expropriação, antes assemelhando-se a uma forma da usucapiăo: "A desapropriação é ato de natureza administrativa e, no caso, o ato do juiz é tipicamente jurisdicional: ele simplesmente resolize um confito de intenesses entre purticulares, decidindo num sentido ou em outro, segundo estejam aterdidos ou não os pressupostos legais. Ojuiz nãopoderá "desapropriar" sem que os interessados opeçam expressamente, até porque eles éque sofrerão os ônus correspondentes, de pagar o preço e serão eles, enão o Poder Público, que adquirivão a propriedade. $O$ Estado sequer épatrte no processo, atuando nele como órgão jurisdiciomal Se fôssemos comparatr com algum instituto já formado e sedimentado em nosso sistema, haveriamos de fazếlo, não com o da desapropriação, mas com o da usucapião. Pelos seus requisitos ("posse ininterrupta e de bra.fe, por mais de cinco anos") assemelha-se à usucapiäo, com a única diferença de que, para adquirir a propriedade, os possuidone-usucapientes ficam sujeitos a pagar um preço. Ou sejac éespécie de usucapião onerosa. Todavia, comparações à parte, o que o nowo instituto faculta ao juiz não é desapropriar o bem, mas sim converter a prestação devida pelos réus, que de especiffca (de restituir a coisa vindicada), passa a ser altemativa (de indenizá-la em dinbeiro). Nosso sistema processual prevê várias hipóteses dessa natumzza, notadamente em se tratando de obrigaçóes de fazer e de obrigaçöes de entregar coisa".
} 


\section{b.2) a função social do contrato}

Assim como reveste e modifica o estatuto proprietátio, a função social também recobre a disciplina das obrigações e dos contratos, até porque entre os deveres positivos que decorrem da função social da propriedade está, por vezes, o dever de contratar. Na literatura portuguesa enfrenta o tema Mario Júlio de Almeida Costa para assegurar que, independentemente dos casos expressos na lei, "o dever de contratar existe, pelo menos quando se trate de uma situação de monopólio de direito ou de fato e de bens ou serviços de importância vital para os particulares ${ }^{186}$, podendo verificar-se também em situações em que "baste que se esteja diante de bens ou serviços de importância vital, mesmo não se verificando uma situação monopolist $a^{187}$.

É que, como tem reiteradamente acentuado Miguel Reale, o princípio da função social do contrato é mero corolário dos imperativos constitucionais relativos à função social da propriedade è à justiça que deve presidir à ordem econômica ${ }^{188}$.

Deixando bem marcada esta perspectiva, o Código exprime, com todas as letras, no art. 421, a função social dos contratos. Com efeito, no Direito dos Contratos ${ }^{189}$, concomirantemente à boa-fé e à probidade vigora o princípio: "A liberdade de contratar será exercida em razão e nos limites da função social do contrato". Essa norma, posta no art. 421 constitui a projeção do valor constitucional expresso como garantia fundamental dos indivíduos e da coletividade que está no art. $5^{\circ}$, XXIII da Constituição Federal, uma vez que o contrato tem, entre outras funções, a de instrumentalizar a aquisição da propriedade. Se a esta não é mais reconhecido o caráter absoluto e sagrado, a condição de direito natural e inviolável do indivíduo, correlatamente, também inflete ao contrato o cometimento - ou o reconhecimento - de desempenhar função que traspassa a esfera dos meros interesses individuais e, ao exercício do poder negocial estão cometidas também funções positivas e negativas.

Assim como ocorre com a função social da propriedade, a atribuição de uma função social ao contrato insere-se no movimento da funcionalização dos direitos subjetivos: atualmente admite-se que os poderes do titular de um direito subjetivo estão condicionados

\footnotetext{
${ }^{186}$ Al.meIDA COSTA, Marto Júlio, Direito das Obrigações, Coimbra, Almendina, $8^{2}$ edição, 2000, p. 211 .

${ }^{187}$ Tdem, ibidem, grifamos.

${ }^{184}$ REALE, Miguel, O Projeto de Código Civil: situação atual e seus problemas fundamentais, São Paulo, Saraiva, 1986, p. 32.

${ }^{189}$ As consideraçōes que seguen acerca da função social do contrato sintetizam o que escrevi em " $\mathrm{O}$ Direito Privado como Construção: as Cláusulas Gerais no Projeto do Código Civil”, cit. ${ }^{186}$ AlMEXDA COSTA, Mario Júlio, Direito das Obrigações, Coimbra,
} 
pela respectiva função ${ }^{199}$, e a categoria do direito subjetivo, posto que histórica e contingente como todas as categorias jurídicas, não vem mais revestida pelo "mito jusnaturalista" que a recobrira na codificação oitocentista, na qual fora elevada ao status de realidade ontológica, esfera juridica de soberania do indivíduo ${ }^{192}$. Portanto, o direito subjetivo de contratar e a forma de seu exercício também são afetados pela funcionalização, que indica a atribuição de um poder tendo em vista certa finalidade ou a atribuição de um poder que se desdobra como dever, posto concedido para a satisfação de interesses não meramente próprios ou individuais, podendo atingir também a esfera dos interesses alheios.

Frase dira e repetida indica que "o contrato é a veste jurídica das operaçôes econômicas", de modo que constitui sua função primordial instrumentalizar a circulação da riqueza, a transferência da riqueza, atual ou potencial, de um patrimônio para outro ${ }^{193}$. A constituição econômica de uma sociedade, todos o sabemos, não é matéria de interesse individual, ou particular, mas atinge - e interessa - a todos. $O$ contrato, veste jurídica das operações de circulação de riqueza, tem, inegavelmente, função social, assim como a disciplina das Obrigações, pois não devemos esquecer, no exame das projeções da direrriz da socialidade, a estrutura sistemática do Código.

Coerentemente a estas percepções, o citado art. 421 afrrma dever o contrato, expressão privilegiada da autonomia privada, ou poder negocial ${ }^{194}$ não mais ser perspectivado apenas como a expressão, no campo negocial, dacuela autonomia ou poder, mas como o instrumento que, principalmente nas economias de mercado, mas não apenas nelas ${ }^{195}$, instrumentaliza a circulação da riqueza da sociedade.

\footnotetext{
19: Ver ALMEIDA COSTA, Mario Júlio, Direito das Obrigações, Ed. Almedina, Coimbra, $B^{*}$ ediçăo, pp. 60 e ss.

${ }^{191}$ A expressão é de Vitorio FROSINI, "Le transformazioni sociali e il diritto soggetivo", Riv. Inter. di Filosofia del Diritto, 1968, I, Milão, pág.114.

192 Idem, ibidem.

:93 Ver ROPPO, Enzo, O Contrato, trad, de Ana Coimbra e M. Januário Gomes, Ed. Almedina, Colmbra, 1988, pp. 10 e ss.

19.s A expressão "poder negocial", de Miguel REALE, remete à concepçăo kelseniana do poder normativo derivado da autonomia privada. Na concepção de REALE, aqui adotada, o poder negocial, que dá origem às cláusulas do contrato, é correlato à fonte negocial de produção de normas jurídicas. Ver O Projeto de Código Civil - Situação atual e seus problemas fundamentais, cit., p. 9.

195 A propósito das funçōes do contrato na economia socialista, ver TALLON, Denis, "L évolution des idées en matière de contrat: survol comparatif", in Droits, 12, 1990, p. 81 e ss.
} 
Colocada no pórtico da disciplina contratual, formando "quase que um preâmbulo de todo o direito contratual ${ }^{M 96}$, a cláusula geral da função social do contrato desempenha um duplo papel. A função social é, evidentemente, e na literal dicção do art. 421, uma condicionante posta ao princípio da liberdade contratual, o qual, reafirmado, está na base da disciplina contratual e constitui o pressuposto mesmo da função (social) que é cometida ao contrato. Ao termo condição pode corresponder uma conotação adjetiva, de limitação da liberdade contratual, podendo e devendo a consideração da função social testringir o exercício da autonomia privada quando esta se mostrar incompativel com as exigências da socialidade. Na sua concreção o juiz poderá, avaliadas e sopesadas as circunstâncias do caso, determinar, por exemplo, a nulificação de cláusulas contratuais abusivas, inclusive para o efeito de formar, progressivamente, catálogos de casos de abusividade.

Contudo, considerar a norma do art. 421 apenas uma restrição à liberdade contratual seria acreditar que esta constitui um princípio absoluto, o que constitui uma falácia há muito desmentida. Por isso entendo estar cometida àquela norma também uma conotação substantiva, vale dizer, de elemento integrante do conceito de contrato. É por ser este dotado de função social que a liberdade contratual encontra limites. É pelo mesmo motivo que esta é regularmente exercida.

Integrando o próprio conceito de contrato, a função social tem um peso específico, que é o de entender-se a eventual restrição à liberdade contratual não mais como uma "exceção" a um direito absoluto, mas como expressão da função meraindividual que integra aquele direito. Há, portanto, um valor operativo, regulador da disciplina contratual, que deve ser utilizado não apenas na interpretação dos contratos, mas, pot igual, na integração e na concretização das normas contratuais particularmente consideradas. Em outras palavras, a concreção especificativa da norma, em vez de já estar pré-constituída, preposta pelo legislador, há de ser construída pelo julgador, a cada novo julgamento, cabendo relevantíssimo papel aos casos precedentes, que auxiliam a fixação da hipótese, e à doutrina, no apontar de exemplos.

A doutrina - sua argúcia e sensibilidade - bem como o sentido de responsabilidade da jurisprudência, não só nesta passagem serão convocadas a atuar, complementando, atualizando e desenvolvendo a letra do Códigos. Doutrina e jurisprudência constituem a matéria da qual um Código é feito. Se é certo que nenhuma lei nasce no vazio, também é certo

\footnotetext{
${ }^{126}$ Miguel Reale, O Projero de Código Civil - Situaçầo atual e seus problemas fundamentais, cit., p. 10.
} 
que nenhuma lei opera no vazio, portanto, a visão prospectiva dos modelos jurídicos e a consciência do caráter dinâmico e processual da construção da normatividade que animaram a Comissão Elaboradora do Projeto do Código Civil brasileiro ${ }^{197}$ deverão agora tornar-se concreta realidade por obra dos destinatários da nova lei.

Para tanto, porém, é preciso ter presente a nova racionalidade do Código, que, não mais pretendendo rudo regular, requer as contribuições da doutrina e da jurisprudência para continuar e completar a sua força normativa, postulando por igual a consciência de todos os cidadãos, destinatários do Código - os reais construtores de sua normatividade - de que "não existe a plenitude do Direito escrito, mas sim a plenitude ético-jurídica do ordenamento" 198 .

${ }^{197}$ Neste sentido o meu "Direito e Cultura: entre as veredas da existencia e da história", Revista do Advogado, n 61, São Paulo, 2000, p. 72.

${ }^{198}$ REALE, Miguel, O Projeto do Novo Código Civil, cit., p. 178. 


\section{BIBLIOGRAFIA}

AGUIAR DIAS, José Da responsabilidade Civil, Rio de Janeiro, Forense, Tomo II, 1994.

AGULAR JUNIOR, Rui Rosado, "Projeto do Código Civil-Obrigaçóes e Contratos", Revista do Conselho da Justiça Federal v.9, Brasília, 1999.

AGUIAR JÚNIOR, Ruy Rosado, “O Poder Judiciário e a concretização das cláusulas gerais: limites e responsabilidades”, Revista da Faculdade de Direito da UFRGS, vol. 18, Porto Alegre, 2000.

ALMEIDA COSTA, Mario Júlio Responsabilidade civil pela ruptura das negociações preparatórias de um contrato, Coimbra, 1984.

ALMEIDA COSTA, Mario Júlio, Direito das Obrigações, Ed. Almedina, Coimbra, $8^{2}$ edição, 2000.

ARCE Y FLORES-VALDEZ, Joaquin, El Derecho Civil Constitucional, Madrid, Civitas, 1986.

ASSIS, Araken, Comentários ao Código de Processo Civil, vol IV, arts. 566 a 645, Rio de Janeito, Forense, $1^{2}$ edição, $4^{2}$ tiragem, 2001.

AVILA, Humberto Bergmann, A Distinção entre Princípios e Regras e a Redefinição do Dever de Proporcionalidade, Revista da Pós-Graduação da Faculdade de Direito da USP, 1, 1999, Porto Alegre, Síntese, 1999, p. 27.

BALLARIN MARCIAL, A.Evolução do princípio jurídico do direito de propriedade rural, Revista de Direito Agtário, n.12, ano 10, 1994, p.28.

BANDEIRA DE MELLO, Celso Antônio. Novos aspectos da função social da propriedade no direito público, São Paulo, Revista de Direito Público, vol. 84, out-dez. 1987.

BITTAR, Carlos Alberto, Reparação Civil por Danos Morais, São Paulo, Revista dos Tribunais, $3^{2}$ edição, $2^{2}$ tiragem, 1999.

BODIN DE MORAES, Maria Celina " $A$ caminho do Direito Civil-Constitucional”, Revista Direito, Estado e Sociedade, PUC, Rio de Janeiro, 1991, p. 59.

BORDA, Alejandro, La Teoria de los Actos Proprios, Buenos Aires, Abeledo-Perrot, $3^{2}$ edição atualizada e ampliada, 2000.

CAHALI, Yussef Said Dano Moral, $2^{2}$ ediçã̀o, São Paulo, Revista dos Tribunais, 1998.

CALERA, Nicolas López, Hay derechos colectivos? Individualidad y socialidad em la teoria de los Derechos, Barcelona, Ariel Derecho, 2000.

CANARIS, Claus Wilhem, Pensamento Sistemático e Conceito de Sistema na 
Ciência do Direito, trad. MENEZES CORDEIRO, Lisboa, Gulbenkian, 1989.

COMPARATO, Fábio Konder, Correspondência dirigida ao Senador Josaphat Marinho em 3.9.97, in O Projeto de Código Civil no Senado, Tomo II, Brasília, Senado Federal, 1998.

COUTO E SILVA, Clóvis, "O princípio da boa-fé no Direito brasileiro e português", in Estudos de Direito Civil Brasileiro e Português, São Paulo, 1986

COUTO E SILVA, A Obrigação como Processo, São Paulo, José Bushatsky, 1976.

COUTO E SILVA, Clóvis, "Observações à Parte Geral do Anteprojeto de Código Civill", dirigidas ao Relator José Carlos MOREIRA ALVES em março de 1970, reproduzidas nas notas de rodapé da "Análise das Observações do Prof. Couto e Silva à Parte Geral do Anteprojetode Código Civil”, in MOREIRA ALVES, José Carlos, A Parte Geral do Projeto de Código Civil,

COUTO E SILVA, Clóvis, "O Conceito de Empresa no Direito Brasileiro", Revista Ajuris vol. 37, Porto $A$ legre,

COUTO E SILVA, "O conceito de dano no Direito brasileiro e comparado", in O Direito Privado Brasileiro na visão de Clóvis do Couto e Silva", ao cuidado de FRADERA, Vera Maria Jacob, Porto Alegre, Livraria do Advogado, 1997.

COUTO E SILVA, Clóvis, "O Direito Civil Brasileiro em Perspectiva Histórica e Visão de Futuro" in Revista Ajuris no 40, Porto Alegre, 1987.

COUTO e SILVA, Clóvis, Exposição de Motivos para a Reforma do Direito de Família, in Anteprojeto do Código civil, Arquivos do Ministério da Justiça, vol. 155, Rio de Janeiro, 1975.

COUTO e SILVA, Clóvis, Direito Patrimonial de Família no Projeto de Código Civil Brasileiro e no Direito Português, São Paulo, RT 520, 1979, p. 14.

CUNHA, Alexandre dos Santos, "Dignidade da Pessoa Humana: conceito fundamental do Direito Civil", in ", in MARTINS-COSTA, Judith, A Reconstrução do Direito Privado - reflexos dos princípios constitucionais e dos direitos fundamentais no Direito Privado, São Paulo, Revista dos Tribunais, no prelo.

DUGUIT, Léon, La responsabilidad del propietario y la jurisprudencia francesa, apend. in: Las transformaciones del Derecho (público y privado), trad. De Carlos POSADA, Buenos Aires, Editorial Heliasta, 1975.

DUGUIT, L., El derecho subjetivo y la función social, in in: Las transformaciones del Derecho (público y privado), trad. De Carlos POSADA, Buenos Aires, Editorial Heliasta, 1975. 
DUGUIT, L. La propiedad función social in in: Las transformaciones del Derecho (público y privado), trad. De Carlos POSADA, Buenos Aires, Editorial Heliasta, 1975.

FACHIN, Luis Edson Teoria Crítica do Direito Civil, Rio de Janeito, Renovar, 2000 FRADERA, Vera Maria JACOB de, "Pertenças", Revista Jurídica 126, Porto Alegre, 1988

FROSINI, Vitório, "Le transformazioni sociali e il diritto soggetivo", Riv. Inter. di Filosofia del Diritto, 1968, I, Milão, pág.114.

GILISSEN, John, Introdução Histórica ao Direito,. Lisboa, Gulbenkian, 1988.

GROSSI, Paolo, La propiedad y las propiedades, un analisis histórico, trad. LÓPEZ Y LÓPEZ, Angel, Madrid, Civitas, 1992.

GROSSI, Paolo, Proprietà - diritto intermedio, verbete in: Enciclopedia del Diritto, vol. XXXVII, 1988.

GROSSI, Paolo, L'Ordine Giuridico Medievale, Laterza, Roma-Bari, 1995.

HATTENHAUER, Hans, Conceptos Fundamentales del Derecho Civil, Barcelona, Ariel, 1987.

HECK, Luis Afonso, "Direitos Fundamentais e sua influência no Direito Civil", in Revista da Faculdade de Direito da UFRGS, vol. 16, Porto Alegre, 1999.

HESSE, Konrad,Derecho Constitucional y Derecho Privado, Madrid, Civitas, 1985.

HOBBES,Thomas, De Cive (Do Cidadão). Tradução de Renato Janine Ribeiro. São Paulo, Martins Fontes.

IONESCU, Octavian, "Leproblème dela partie introductize du code civil", Revue International de Droit Comparé, 1967, n.3, p. 579.

IRTI, Natalino, L'età della decodificazione Milão, Giuffrè, 1989.

IRTI, Natalino, Codice Civile e Società Politiche, Roma, LATERZA,1999.

KRELL, Andreas, Controle Judicial dos Serviços Públicos Básicos na Base dos Direitos Fundamentais Sociais, in A Constituição Concretizada, org., SARLET, Ingo Wolfgang, Porto Alegre, Livraria do Advogado, 2000.

LAFER, Celso, A reconstrução dos Direitos Humanos: um diálogo com o pensamento de Hannah Arendt. São Paulo, Companhia das Letras, $19911^{2}$ reimpressão.

LUDWIG, Marcos de Campos, "O direito ao livre desenvolvimento da personalidade na Alemanha e possibilidades de sua aplicação no Direito privado brasileiro", in MARTINSCOSTA, Judith, A Reconstrução do Direito Privado - reflexos dos princípios constitucionais e dos direitos fundamentais no Direito Privado, São Paulo, Revista 
dos Tribunais, no prelo.

MAC-DONALD, Norberto da Costa Caruso, O Projeto de Código Civil e o Direito Comercial, Revista da Faculdade de Direito da UFRGS, vol. 16, Porto Alegre, 1999.

MARINHO, Josaphat, "Os Direitos de Personalidade no Projeto do Código Civil", Boletim da Faculdade de Direito da Universidade de Coimbra, col. Stvdia Juridica, 40, Coimbra, 2000 .

MARINHO, Josaphat, Parecer Final ao Projeto do Código Civil, in O Projeto de Código Civil no Senado Federal, Vol. I, Brasília,

MARTINS-COSTA Da Boa-Fé no Direito Privado, São Paulo, Revista dos Tribunais, 1999.

MARTINS-COSTA, Judith O sistema na Codificação Civil Brasileira - de Leibniz a Teixeira de Freitas", Revista da Faculdade de Direito da UFRGS vol. 17, Porto Alegre, 1999.

MARTINS-COSTA, Judith, "Os Danosà Pessoa e a Natureza de sua Reparação", Revista da Faculdade de Direito da Universidade Federal do Rio Grande do Sul vol. 19, Porto Alegre, 2000.

MARTINS-COSTA, Judith, Bioética e dignidade da Pessoa Humana: Rumo à Construß̧ão do Biodireito", Revista da Faculdade de Direito da Universidade Federal do Rio Grande do Sul vol. 18, Porto Alegre, 2000.

MARTINS-COSTA,Judith, "O Direito Privado como Construção: as Cláusulas Gerais no Projeto do Código Civil Brasileiro", Revista de Informação Legislativa vol. 139, Brasihia, 1998.

MARTINS-COSTA, Judith, Direito e Cultura: entre as veredas da existência e da bistória", Revista do Advogado, $\mathrm{n}^{\circ}$ 61, São Paulo, 2000, p. 72.

MARTINS-COSTA, Judith, Mercado e solidariedade social entre cosmos e taxis: a boa-fé nas relações de consumo, , in A Reconstrução do Direito Privado reflexos dos princípios constitucionais e dos direitos fundamentais no Direito Privado, São Paulo, Revista dos Tribunais, no prelo.

MENEZES CORDEIRO, António Manuel, Da Boa-Fé no Direito Civil, Coimbra, Almendina, 1989.

MEDEIROS DA FONSECA, Anoldo. Dano Moral, verbete in Repertório Enciclopédico Brasileiro.

MESSINETTI, Davide, "Personalitá"(Diritti della), verbete, in Enciclopedia Giuridica, Giuffrè, Milão, 1984.

MIRANDA, Jorge (org.). Textos Históricos do Direito Constitucional, Lisboa, Imprensa Nacional - Casa da Moeda, 1980. 
MORErRA Alves, José Carlos, A Parte Geral do Projeto de Código Civil Brasileiro, São Paulo, Saraiva, 1986, p. 7.

MOISSET DE ESPANES, Luis, La lesión los Actos Juridicos, Cordoba, Victor P. De Zavalia Editor, 1979

MOREIRA ALVES, parecer in O Projeto de Código Civil no Senado, Tomo II, Brasilia, Senado Federal, 1998.

NICOLAU, Noemi Nidia, "La autonomia de la voluntad como factor de resistencia a la tipicidad en el sistema de derecho privado argentino", Porto Alegre, nov. 1994, datilog..

NEGREIROS, Teresa, Fundamentos para uma interpretação constitucional do princípio da boa-fé, Rio de Janeiro, Renovar, 1998.

OPPO, Giorgio, "Diritto Privato e Interessi Pubblici", in Rivista di Diritto Civile, 1994, 1 , p.26.

PACHECO BARROS, Wellington, A propriedade agrária e seu novo conceito jurídico constitucional, Porto Alegre, Revista Ajuris, $n^{\circ} 32$.

PENTEADO, Mauro Rodrigues, "Exposição Justificativa da Proposta de Modificação do Título VIII, Livro I, Parte Especial, do Projeto de Código Civil (PLC no 118/84)que dispõe sobre os Títulos de Crédito", in O Projeto de Código Civil no Senado, Tomo II, Brasília, Senado Federal, 1998.

PERLINGIERI, Pietro,Il Diritto Civile nella legalità costituzionale”, Nápoles, Edizione Scientifiche Italiane, 1991,

PONTES DE MIRANDA, F.C, Fontes e Evolução do Direito Civil Brasileiro, Rio de Janeiro, Forense, 1981.

PONTES DE MIRANDA, Tratado de Direito Privado, Tomo II, Rio de Janeiro, Borsói,

PONTES DE MIRANDA Tratado de Direito Privado, T. 26, Ed. Borsói, Rio de Janeiro, 1959.

PORTO, Sérgio José A Responsabilidade Civil por Difamação no Direito Inglês, Ed. Sergio Fabris, Porto Alegre, 1995.

PROUDHON. Qu'est-ce que la propriété, in Oeuvres Choisies. Paris, Gallimard, 1967.

RAISER, Ludwig, "Il futuro del Diritto Privato", in: Il Compito del Diritto Privato, trad. Italiana de Marta Graziadei, Milão, Giuffrè, 1990.

REALE, Miguel, Memórias - vol. 2 - a Balança e a Espada, São Paulo, Saraiva, 1987, p. 221. 
REALE, Miguel, O Projeto de Código Civil - Situação atual e seus problemas fundamentais, São Paulo, Saraiva, 1986.

REALE, Miguel, O Projeto do Novo Código Civil - situação após a aprovação pelo Senado Federal, São Paulo, Saraiva, 2000.

REALE Fundamentos do Direito, São Paulo, Revista dos Tribunais, 3a. edição, 1998.

REALE, Miguel, Pluralismo e Liberdade ,Rio de Janeiro, Expressão e Cultura, $2^{a}$ edição, 1998.

REALE, Miguel, Código Civil - Anteprojetos, vol. 5, Tomo 1, Senado Federal, Subsecretaria de Edições Técnicas, Brasilita, 1989.

REALE, Miguel, O Direito como Experiência, São Paulo, Saraiva, 1968.

REALE, Miguel, Fontes e Modelos do Direito - para um novo paradigma hermenêutico, São Paulo, Saraiva, 1994.

RIBETRO LOPES, Mauricio, Dignidade da Pessoa Humana, in Revista dos Tribunais $758 /$ 106-117.

RODOTÀ, Stefano, El terrible derecho- Estudios sobre la propiedad privada, Madri, Civitas, 1986.

ROPPO, Enzo, O Contrato, trad., de Ana Coimbra e M. Januário Gomes, Ed. Almedina, Coimbra, 1988.

SENADO FEDERAL, O Projeto de Código Civil no Senado, Tomo II, Brasilia, Senado Federal, 1998.

SILVA PEREIRA, Caio Mario, Instituições de Direito Civil, v. 1, nº 16.

SILVA PEREIRA, Caio Mario, Lesão nos Contratos, Rio de Janeito, Forense, $4^{2}$ Edição, 1993.

TALLON, Denis, "L'évolution des idées en matière de contrat: survol comparatif", in Droits, $12,1990$.

VARELA, Laura Beck, " $A$ Tutela da Posse entre abstrạ̧ão e autonomia: uma abordagem bistórica," in A Reconstrução do Direito Privado - reflexos dos princípios e garantias fundamentais no Direito Privado, MARTINS-COSTA, Judith (org)., no prelo.

ZAVASKI. Teori, "A tutela da posse na Constituição e no Projeto do novo Código Civil", in MARTINS-COSTA, Judith, A Reconstrução do Direito Privado - reflexos dos princípios e garantias fundamentais no Direito Privado, no prelo. 